University of California, Hastings College of the Law UC Hastings Scholarship Repository

Faculty Scholarship

1998

\title{
The McCleskey Puzzle: Remedying Prosecutorial Discrimination Against Black Victims in Capital Sentencing
}

Ashutosh Bhagwat

UC Hastings College of the Law, aabhagwat@ucdavis.edu

Evan Tsen Lee

Follow this and additional works at: http://repository.uchastings.edu/faculty_scholarship

Part of the Civil Rights and Discrimination Commons

\section{Recommended Citation}

Ashutosh Bhagwat and Evan Tsen Lee, The McCleskey Puzzle: Remedying Prosecutorial Discrimination Against Black Victims in Capital Sentencing, 1998 Sup. Ct. Rev. 145 (1998).

Available at: http://repository.uchastings.edu/faculty_scholarship/25

This Article is brought to you for free and open access by UC Hastings Scholarship Repository. It has been accepted for inclusion in Faculty Scholarship by an authorized administrator of UC Hastings Scholarship Repository. For more information, please contact marcusc@uchastings.edu. 


\title{
UNIVERSITY of CALIFORNIA HASTINGS COLLEGE OF THE LAW
}

\section{Faculty Publications}

UC Hastings College of the Law Library

\author{
Author: $\quad$ Ashutosh Bhagwat \\ Source: $\quad$ Supreme Court Review \\ Citation: 1998 Sup. CT. ReV. 145 (1998). \\ Title: $\quad$ The McCleskey Puzzle: Remedying Prosecutorial Discrimination Against Black \\ Victims in Capital Sentencing
}

Originally published in SUPREME Court ReVIeW. This article is reprinted with permission from SUPREME COURT REVIEW and University of Chicago School of Law. 
In this article we analyze possible legislative and judicial alternatives for redressing prosecutorial race discrimination against murder victims. There are both substantive and procedural obstacles to such remedies. The substantive obstacle is the doctrine that requires proof of intentional discrimination to make out a violation of the Equal Protection Clause. The procedural obstacles arise out of the standing doctrine and the law of official immunity. We conclude that the most promising remedies are to commute the death sentences of defendants whose victims' lives have been overvalued on the basis of race and to award damages to the families of murder victims whose lives have been undervalued on the basis of race.

Evan Tsen Lee is Professor of Law, University of California, Hastings College of Law. Ashutosh Bhagwat is Associate Professor of Law, University of California, Hastings College of Law.

Authors' note: We would like to thank Vik Amar, David Faigman, and Rory Little for their helpful comments and Alyson Lewis and Matt Borden for excellent research assistance.

(C) 1999 by The University of Chicago. All rights reserved.

0-226-36316-3/99/1998-0002\$02.00 


\section{McCleskey v Kemp and Discrimination in Capital SENTENCING}

We begin with $M c$ Cleskey $v$ Kemp $p^{1}$ because, although the scope of our inquiry considerably exceeds the factual radius of McCleskey, the topic of prosecutorial race discrimination among murder victims simply cannot be comprehended without reference to that decision. In 1978, Warren McCleskey was sentenced to death by a Georgia jury for the murder of a white police officer. The killing occurred during the course of an armed robbery committed by McCleskey and three accomplices. ${ }^{2}$ McCleskey was "eligible" for the death penalty because of two aggravating factors found by the jury: the murder was committed during the course of an armed robbery, and it was committed on a peace officer engaged in the performance of his duties. ${ }^{3}$ McCleskey eventually brought a petition for a writ of habeas corpus in federal district court, arguing that "the Georgia capital sentencing process is administered in a racially discriminatory manner in violation of the Eighth and Fourteenth Amendments to the United States Constitution." ${ }^{4}$

McCleskey's primary evidence in support of this claim was the so-called Baldus study, a sophisticated statistical analysis performed by Professors David C. Baldus, Charles Pulaski, and George Woodworth of the role played by race in capital sentencing proceedings in Georgia in the 1970s. The Baldus study was based on data from more than 2,000 Georgia murder cases during the relevant period. It considered 230 potentially relevant, nonracial variables that might explain disparities in capital sentencing. The

1481 US 279 (1987).

${ }^{2}$ Warren McCleskey was executed by the State of Georgia in 1991. See Peter Applebome, Georgia Inmate Is Executed After "Chaotic" Legal Move, New York Times A18 (September $26,1991)$. He had the dubious distinction of producing in the course of his appeals not one but two Supreme Court decisions that were highly unfavorable to capital defendants. See McCleskey v Kemp, 481 US 279 (1987); McCleskey v Zant, 499 US 467 (1991) (establishing "abuse of writ" rule prohibiting defendants from filing successive federal writs of habeas corpus, absent a showing of "cause and prejudice").

${ }^{3}$ McCleskey, 481 US at 283-85.

${ }^{4} \mathrm{Id}$ at 286 . This article will not discuss McCleskey's claim that racial discrimination in capital sentencing violates the Eighth Amendment's prohibition on "Cruel and Unusual Punishment," primarily to keep our inquiry within manageable proportions, but also because we believe that both historically and doctrinally, the Equal Protection Clause offers the best fit for addressing discrimination against black murder victims. 
Baldus study is generally accepted within the social scientific community as a thorough, carefully conducted analysis, and its results as almost certainly statistically valid. ${ }^{5}$

The results of the Baldus study are striking. The race of the victim was an overwhelmingly important indicator of the likelihood that a capital sentence would be imposed. After controlling for the thirty-nine most relevant nonracial variables, murderers of whites were 4.3 times as likely to receive a death sentence as murderers of blacks. ${ }^{6}$ The race of the defendant was hardly influential at all: black defendants were only 1.1 times (i.e., $10 \%$ ) more likely to receive a death sentence than white defendants, and later writings by the authors of the Baldus study suggest that this result is not statistically significant. ${ }^{7}$ Furthermore, the Baldus study's findings regarding the prevalence of race-of-victim discrimination in capital sentencing (and indeed its findings regarding the lack of race-of-defendant discrimination) are fully supported by other social scientific research. ${ }^{8}$

In addition to its findings regarding end-result discrimination, the Baldus study also sheds light on the loci of discrimination

\footnotetext{
${ }^{5}$ See Randall L Kennedy, McCleskey $v$ Kemp: Race, Capital Punishment, and the Supreme Court, 101 Harv L Rev 1388, 1398-1400 and nn 40-47. It should be noted that while the District Court in the McCleskey case questioned the validity of the study, both the Court of Appeals and the Supreme Court assumed its validity. McCleskey, 481 US at 291 n 7. Moreover, the grounds upon which the District Court questioned the study appear to have been ill-informed, and almost certainly incorrect as a matter of statistical methodology. For a discussion, see Kennedy, 101 Harv L Rev at 1400 and nn 44-45.
}

${ }^{6}$ McCleskey, 481 US at 287.

${ }^{7}$ See Kennedy (cited in note 5), 101 Harv L Rev at 1390-91 n 13 (citing David C. Baldus, George Woodworth, and Charles Pulaski, Arbitrariness and Discrimination in the Administration of the Death Penalty: A Challenge to State Supreme Courts, 15 Stetson L Rev 133, 158 (1986); Baldus, Woodworth, and Pulaski, Monitoring and Evaluating Contemporary Death Sentencing Systems: Lessons from Georgia, 18 UC Davis L Rev 1375, 1404 (1985)); Baldus, Woodworth, and Pulaski, Equal fustice and the Death Penalty 185 (1990) ("Statewide, we see no evidence of race-of-defendant discrimination").

${ }^{8}$ In 1990, the General Accounting Office issued a report summarizing and analyzing existing studies regarding the role played by racial factors in capital sentencing. U.S. General Accounting Office, Death Penalty Sentencing: Research Indicates Pattern of Racial Disparities (1990) ("GAO Report"), cited in Note, Easing the Fear of Too Much fustice: A Compromise Proposal to Revise the Racial 7ustice Act, 30 Harv CR-CL L Rev 543, 543 and n 4 (1995). After reviewing a large number of studies that themselves examined a variety of state systems and spanned a time period from 1979 to 1990 , the Report concluded unambiguously that the findings of race-of-victim discrimination were "remarkably consistent." As with the Baldus study, however, the studies were less likely to find race-of-defendant discrimination, and if found, such discrimination was likely to be less serious. GAO Report at 5-6 (quoted in Note, 30 Harv CR-CL L Rev at 544-45). 
within the capital sentencing system. While the study found discrimination in every stage of the process, ${ }^{9}$ it found race to be particularly important in the charging decision made by prosecutors following a jury conviction for murder. Prosecutors were many times more likely to seek the death penalty in a case involving a white victim than in a case involving a black victim. Once again, these results were statistically significant after being subjected to a multivariate regression analysis; ${ }^{10}$ and, once again, other research fully confirms these findings. ${ }^{11}$

Despite these results, the Supreme Court, as well as every other court to hear the case, rejected McCleskey's claim of a constitutional violation. ${ }^{12}$ The basis for the Court's holding was that to prove an equal protection violation, McCleskey was required to "prove that the decisionmakers in his case acted with discriminatory purpose." According to the Court, the statistical findings of the Baldus study, without more, were inadequate to establish purposeful discrimination. ${ }^{13}$ The Court's primary objection to $M c C l e s k e y ' s$ claim appeared to be that he was unable to prove that any of the specific actors in his case, whether it be the prosecutor, judge, or jurors, had acted with discriminatory intent. According to the Court, statistical evidence alone could not make out such proof because, given the large number of factors that are potentially relevant to the charging and sentencing decisions, there

${ }^{9}$ McCleskey, 481 US at 350-51 (Blackmun, J, dissenting); id at $356 \mathrm{n} 11$ (Blackmun, J, dissentirg).

${ }^{10}$ Id at 350-51, 356-57 (Blackmun, J, dissenting); Baldus, Woodworth, and Pulaski, Equal Fustice and the Death Penalty 162 (1990); Note, Easing the Fear of Too Much 7ustice: A Compromise Proposal to Revise the Racial 7ustice Act, 30 Harv CR-CL L Rev 543, 549 n 22 (1995).

${ }^{11}$ See Kennedy, 101 Harv L Rev at 1435 n 213 (citing Joseph E. Jacoby and Raymond Paternoster, Sentencing Disparity and Fury Packing: Furtber Challenges to the Death Penalty, 73 J Crim L \& Criminol 379 (1982); Raymond Pasternoster, Race of Victim and Location of Crime: The Decision to Seek the Death Penalty in South Carolina, 74 J Crim L \& Criminol 754 (1983); Michael L. Radelet and Glenn L. Pierce, Race and Prosecutorial Discretion in Homicide Cases, 19 L \& Society Rev 587 (1985)); Baldus, Woodworth, and Pulaski, Equal fustice and the Death Penalty 257 (1990) (citing Raymond Pasternoster, Prosecutorial Discretion in Requesting the Death Penalty: A Case of Victim-Based Racial Discrimination, $18 \mathrm{~L}$ \& Society Rev 437 (1984); Elizabeth Lynch Murphy, Application of the Death Penalty in Cook County, 73 Ill Bar J 90 (1984)); Thomas J. Keil and Gennaro F. Vito, Race and the Death Penalty in Kentucky Murder Trials: 1976-1991: A Study of Racial Bias as a Factor in Capital Sentencing, http://dpa.state.ky.us/ rwheeler/archives/race/vito.txt, p. 8 (1995).

${ }^{12} \mathrm{McCleskey,} 481$ US at 289-91.

${ }^{13}$ Id at $292-94$. 
could be no confidence that race played a role in any particular case. ${ }^{14}$ In the Court's words, "[A]t most, the Baldus study indicates a discrepancy that appears to correlate with race." 15 The Court asserted that the statistical evidence of the Baldus study did not make out even a prima facie case that McCleskey himself was subjected to racial discrimination "because a legitimate and unchallenged explanation for the decision [to sentence McCleskey to death] is apparent from the record: McCleskey committed an act for which the United States Constitution and Georgia laws permit imposition of the death penalty." 16

Some implications quite plainly follow from the extensive raceof-victim discrimination that exists in capital sentencing. First, if the death penalty in fact has any deterrent value, then the disinclination to impose the penalty in black-victim cases would tend to increase the murder rate against blacks, and thus systematically provide blacks less protection. ${ }^{17}$ Second, even if the death penalty does not deter, the disinclination to impose the penalty in blackvictim cases imposes intangible but important harms on black victims' families because it denies them the sense of closure and "justice" that the death penalty affords, and also stigmatizes them as inferior in the eyes of the law. ${ }^{18}$

\footnotetext{
${ }^{14}$ Id at 295 and $n 15$.

${ }^{15}$ Id at 312. The Court's description of the study is inaccurate because a multivariate regression sbows more than a mere correlation; if the underlying model is properly specified and relevant independent variables are properly included, as was apparently the case with the Baldus study, such an analysis tends to show causation, since other possible explanations bave been accounted for and rejected by the model. For a more detailed discussion, see Part II.

${ }^{16}$ Id at 297.

${ }^{17}$ For similar arguments, see Kennedy, 101 Harv L Rev at 1425 (cited in note 5); Stephen L. Carter, When the Victims Happen to Be Black, 97 Yale L J 444 (1998). Of course, the deterrent effects of the death penalty remain highly controversial, with many studies concluding that such effects are small or nonexistent. See Note (cited in note 8), 30 Harv CRCL L Rev at 547 and n 14 (citing Hugo Adam Bedau, The Death Penalty in America 95185 (3d ed 1982); Walter Berns, For Capital Punishment: Crime and the Morality of the Death Penalty 83-127 (1979); Mark Tushnet, The Death Penalty 5-10, 134 nn 5-8 (1994)); Kennedy, 101 Harv L Rev at 1425 and n 171 (cited in note 5).

${ }^{18} \mathrm{~A}$ primary, if not the only, function performed by the death penalty in our society is retributive - the death penalty serves to satisfy society's, and a victim's friends' and family's, need for retribution and justice. Viewed in this light, the death penalty is a benefit that the law dispenses to the survivors of murder victims, apparently in a highly discriminatory manner.
} 


\section{Equal Protection as Protecting Equally: The Problem of Intent}

The systematic race-of-victim discrimination that infects the administration of the death penalty would seem to seriously implicate the equal protection rights of blacks who are potential or actual victims of crime. Indeed, such discrimination conflicts with one of the core, historical objectives of the Equal Protection Clause, which was to require southern states to protect newly freed slaves from private violence by southern whites, and to prosecute those who engaged in violence against blacks in the same manner that they prosecuted those who attacked whites. ${ }^{19}$ But to establish an actual violation of these rights, such black victims must satisfy the "purposeful discrimination" requirement of McCleskey and the Supreme Court's modern equal protection doctrine.

$M c$ Cleskey rested on the "intent" requirement of modern equal protection doctrine. Since its landmark decision in Washington $v$ Davis in $1976,^{20}$ the Supreme Court has consistently held that in order to establish a violation of the Equal Protection Clause based on racial discrimination, a litigant must show that the state has engaged in purposeful, or intentional, discrimination. Mere statistical disparity, or unequal effect, will not suffice. Thus, in Arlington Heights $v$ Metropolitan Housing Dev. Corp., ${ }^{21}$ the Court rejected an equal protection challenge to a city's zoning ordinance even though it excluded low-income housing residents, a large percentage of whom were minorities (primarily blacks). More recently, in

\footnotetext{
${ }^{19}$ As Justice Blackmun pointed out in his dissent in McCleskey, southern violence against blacks was very much in the minds of the drafters of the Equal Protection Clause. See McCleskey, 481 US at 346-47 and n 2 (Blackmun, J, dissenting) (quoting extensive testimony before the Joint Committee on Reconstruction of violence against blacks, and inaction by state officials). Furthermore, just three years after the ratification of the Fourteenth Amendment, Congress enacted legislation enforcing the Amendment, the $\mathrm{Ku}$ Klux Klan Act of 1871, which specifically targeted private southern violence against blacks. See Act of April 20, 1871, ch 22, 17 Stat 13; Briscoe v LaHue, 460 US 325, 337-38 (1983); Robert J. Kaczorowski, The Nationalization of Civil Rigbts 166 and n 10 (1987); John Harrison, Reconstructing the Privileges and Immunities Clause, 101 Yale L J 1385, 1427 and nn 213-15 (1992); Earl A. Maltz, The Concept of Equal Protection of the Laws $\rightarrow$ a Historical Inquiry, 22 San Diego L Rev 499, 521-22 (1985).

${ }^{20} 426$ US 229 (1976). The Davis Court held that the Equal Protection Clause was not violated by the Washington, D.C., Police Department's use of a written examination to screen applicants, even though the test disqualified black applicants at a much higher rate than whites.
}

21429 US 252 (1977). 
Personnel Administrator $v$ Feeney, ${ }^{22}$ the Court held that a Massachusetts law granting a preference in state hiring to veterans did not violate the Equal Protection Clause even though the law sharply reduced the public employment opportunities available to women (because the vast majority of eligible veterans are men). Crucially, in Feeney the Court noted that it would not matter for equal protection purposes that the legislators knew at the time they adopted the preference that the law would disadvantage women, so long as it was not the reason for their decision. The Court explained that the Equal Protection Clause would not be violated unless the government acted "at least in part 'because of,' not merely 'in spite of,' its adverse effect upon an identified group." 23

The zenith of the "intent" standard-some would say the na$\mathrm{dir}^{24}$ - was McCleskey. Justice Powell's majority opinion rejected McCleskey's challenge to the Georgia death penalty system because he had failed to prove that he was the victim of intentional discrimination, ${ }^{25}$ invoking the language in Feeney that intentional discrimination must occur "because of," not merely "in spite of," race. ${ }^{26}$ In particular, the Court held that the purely statistical evidence presented by McCleskey (i.e., the Baldus study) did not demonstrate that any state actor had purposefully discriminated in McCleskey's own case. Nor, in the Court's estimation, did it demonstrate that Georgia had adopted or maintained its death penalty system as a whole "because of" its racially skewed impact. The Court therefore concluded that McCleskey had not proven a violation of the Equal Protection Clause.

What does "intent" mean in the equal protection context? Some have equated discriminatory intent with "malice," or a desire to harm a subjugated group. ${ }^{27}$ Others have equated intent with con-

${ }^{22} 442$ US 256 (1979).

${ }^{23}$ Id at 279. See also City of Memphis $v$ Greene, 451 US 100, reh'g den 452 US 955 (1981) (rejecting claim that a city's decision to close a street within a white neighborhood used primarily by black motorists constituted "intentional" discrimination).

${ }^{24} \mathrm{McCleskey}$ has been variously described as the "most troubling," and "most controversial and, to some, notorious" of the cases applying the intent rule. See Theodore Eisenherg and Sheri Lynn Johnson, The Effects of Intent: Do We Know How Legal Standards Work? 76 Cornell L Rev 1151, 1159-60 (1991) ("most troubling"); Daniel Ortiz, The Myth of Intent in Equal Protection, 41 Stan L Rev 1105, 1142 (1989) ("most controversial").

${ }^{25}$ McCleskey $v$ Kemp, 481 US 279, 292-93, 298-99 (1987).

${ }^{26} \mathrm{Id}$ at 298.

${ }^{27}$ See, e.g., Reva Siegel, Wby Equal Protection No Longer Protects: The Evolving Forms of Status-Enforcing State Action, 49 Stan L Rev 1111, 1134-35 (1997); Linda Hamilton Krieger, 
scious awareness or deliberate behavior. ${ }^{28}$ However, these understandings are inadequate and inconsistent with the Court's own case law. ${ }^{29}$ The notion that intent equates to malice is peculiar. ${ }^{30}$ Imagine a state official who refused to hire racial minorities into government jobs not because he disliked minorities, but only because he wished to benefit his own ethnic group by hiring them. Surely such actions would constitute "intentional" discrimination. Consider also Palmore $v$ Sidoti, where the Court unanimously held that a state's denial of child custody to a divorced mother because she was part of a interracial couple violated the Equal Protection Clause, even though the denial of custody was motivated by "the best interests of the child" in that the state's purpose was to protect the child from the discrimination that such couples are likely to face. ${ }^{31}$ Palmore seems to establish quite clearly that intent may exist without malice.

The reasons why "intent" cannot be equated with conscious awareness are more complex, but ultimately also powerful. Feeney establishes that conscious awareness of harm, standing alone, does not constitute discrimination, and that intent is not the same thing as consciousness. But Feeney does not exclude the possibility that conscious awareness may be a necessary element of intent. In considering this issue it is necessary to first ask what else "intent"

The Content of Our Categories: A Cognitive Bias Approach to Discimination in Equal Employment Opportunity, 47 Stan L Rev 1161, 1177 (1995); Kennedy, 101 Harv L Rev at 1404-05 (cited in note 5).

${ }^{28}$ See, e.g., Barbara J. Flagg, "Was Blind, But Now I See": White Race Consciousness and the Requirement of Discriminatory Intent, 91 Mich L Rev 953, 980 (1993); see generally Michael Selmi, Proving Intentional Discrimination: The Reality of Supreme Court Rhetoric, 86 Georgetown L J 279, 288-89 and n 5 (1997).

${ }^{29} \mathrm{Id}$ at $288-89$.

${ }^{30}$ Recent cases establish quite clearly that proof of malice is not required to challenge government action that is explicitly race-based. The Court in recent years has invalidated on equal protection grounds many state and federal affirmative action programs designed to benefit racial minorities. See, e.g., Adarand Constructors, Inc. $v$ Pena, 515 US 200 (1995); City of Richmond $v 7 A$ Croson Co., 488 US 469 (1989); see also Hopwood v Texas, 78 F3d 932 (5th Cir 1996), cert den 116 S Ct 2580 (1996). No one would seriously suggest that such programs are motivated hy malice against their white "victims." Nonetheless, such programs are regularly struck down. In another line of recent cases, involving racially based resdistricting, the Court has invalidated "majority-minority" legislative districts drawn in unusual shapes for the apparent purpose of enhancing the voting power of racial minorities. See, e.g., Bush v Vera, 116 S Ct 1941 (1996); Miller v Fobnson, 515 US 900 (1995); Shaw $v$ Reno, 509 US 630 (1993). Once again, the creation of such districts cannot seriously be ascribed to "malice" toward whites, but they have been nonetheless held to "intentionally discriminate."

${ }^{31} 466$ US 429 (1984). 
could possibly be. If neither malice nor conscious awareness is intent, then what is it? In a recent paper, Michael Selmi points out that when one examines the Court's "intent" decisions closely, especially Feeney and McCleskey, what the Court really seems to mean by intent is causation-whether, in fact, particular government conduct was caused by the race of the adversely affected parties. Such an explanation is consistent with the "because of" language of Feeney and McCleskey, and with the reasoning and results in the vast majority of the Court's decisions, in a way that no other theory can match. ${ }^{32}$ The term "causation," as used here, is essentially equivalent to the concept of "but for" causation as used in tort and criminal law, rather than "legal" or "proximate" cause. There are some practical differences between causation in this context and criminal or tort causation, particularly in terms of ease of proof, but the fundamental inquiry is the same. In the tort and criminal contexts, but-for causation generally turns on whether as a matter of objective, physical fact a particular outcome resulted from the particular conduct by an individual. Causation in the equal protection context requires an examination of the decisionmaking process engaged in by a government actor to determine if race was a determinative input into that process (for this reason, it is not incongruous to use the term "intent" to describe this analysis). Note that even the equal protection causation test is not primarily an inquiry into the subjective state of mind of the decision maker. Instead, it seeks to determine whether the ultimate result would have been the same if the races of the affected individuals were different with all other factors left unchanged. ${ }^{33}$

Assuming that the best reading of the Court's cases is that "intent" in the equal protection context refers to causation, the question left open in Feeney remains: whether the intent standard requires that the relevant government actors be conscious that race

\footnotetext{
${ }^{32}$ See Selmi, 86 Georgetown L J at 289-94 (cited in note 28); see also George Rutherglen, Discrimination and Its Discontents, 81 Va L Rev 117, 127 (1995); Paul J. Gudel, Beyond Causation: The Interpretation of Action and the Mixed Motives Problem in Employment Discrimination Law, 70 Tex L Rev 17, 93 (1991).

${ }^{33}$ This understanding of "intent," as essentially an inquiry into causation, is probably best expressed by David Strauss's proposed "reversing the groups" test: to determine if intentional discrimination exists, one must ask whether if the race (or gender) of the affected individuals had been reversed, the same action would have been taken. Selmi, 86 Georgetown L J at 291-94 (cited in note 28) (citing David Strauss, Discriminatory Intent and the Taming of Brown, 56 U Chi L Rev 935, 958 (1989)).
} 
has affected their decision making. Of course, this issue arises only if one believes that certain kinds of mental processes can be influenced, even decisively influenced, by factors of which the person is unaware. In the late twentieth century, however, few people would seriously deny that some mental processes occur below the conscious level. As Charles Lawrence has demonstrated, overwhelming psychological evidence supports the proposition that racism, meaning decision making influenced by racial factors, is one of those processes that often occurs within the unconscious. ${ }^{34}$ What, then, is the constitutional status of governmental action caused by racial factors-meaning that if race alone had been different, the state would have acted differently-but where the government actor was not consciously aware of those racial factors?

The Court has never squarely considered the possibility. There are, however, strong reasons why the government actor's conscious mental state should be irrelevant to the constitutional analysis. If a plaintiff is able to prove that government action was taken because of race, to ask the plaintiff to further prove that the state actor was consciously aware of this fact imposes an almost insurmountable burden of proof (except in the rare instance where the decision maker admits the awareness). It is also not clear what policies would be advanced by such a requirement. ${ }^{35}$ Moreover, the argument in favor of a purely causation-based approach to intent, powerful as it is when applied to individual governmental decision makers, becomes overwhelming when the government conduct at issue is the product of collective decision making, as many discriminatory state policies are. In the collective context, the concept of conscious intent is not merely difficult to prove, it is meaningless. Groups do not have mental states, and while individual members of groups might be shown to possess particular mental states, there is no evident reason to attribute the motive of any particular indi-

\footnotetext{
${ }^{34}$ Charles R. Lawrence III, The Id, the Ego, and Equal Protection: Reckoning with Unconscious Racism, 39 Stan L Rev 317, 328-44 (1987). We concede that it may be controversial to use the word "racism" to describe such unconscious racially influenced behavior. Terminology, however, is beside the point-the issue is whether such behavior is proscribed by the Equal Protection Clause.

${ }^{35}$ See Selmi, 86 Georgetown L J at 294 (cited in note 28); Charles R. Lawrence III, 39 Stan L Rev 317 (cited in note 28); Paul Brest, Foreword: In Defense of the Antidiscrimination Principle, 90 Harv L Rev 1, 14-15 (1976).
} 
vidual to the group as a whole. Causation, on the other hand, remains a coherent (though complex) inquiry in the group context. As a consequence, when assessing the constitutionality of collective decision making, a causation analysis is not only a possible mode of inquiry in defining intent, it is the most coherent mode of inquiry.

The above discussion of the meaning of the intent standard and its proper application in the context of unconscious racism and collective decision making is crucial to a proper assessment of McCleskey. The racial disparities observed in modern death penalty schemes, especially the differing treatment of victims of different races, are almost certainly not a product of racial animus, and indeed probably not even of conscious racism. ${ }^{36}$ Instead, the results are probably best explained as a result of a selective indifference on the part of prosecutors (and jurors) toward the plight of black victims. In short, decision makers, whether consciously or not, do not value the lives of black victims at the same level as they value the lives of white victims, leaving aside for now the question of which valuation is "correct." 37 Race is thus a causal factor with respect to government decision making in this context, in the sense that it is a but-for cause, even if it is not the motive for the decision or even in the conscious awareness of the various actors. That should be sufficient to establish a violation of the Equal Protection Clause.

One further matter merits discussion. It is possible that prosecutors (many of whom are elected) are choosing not to punish murderers of blacks in the same way as murderers of whites not because the prosecutors value the lives of black victims less, but because they perceive that the public does so. These prosecutors may wish to maximize their political gain from death penalty prosecutions, or to maximize their probability of obtaining a verdict of death from juries who are infected by the same biases as the general public. ${ }^{38}$ The Court's decision in Palmore $v$ Sidoti makes

\footnotetext{
${ }^{36}$ See Randall L. Kennedy, McCleskey v Kemp: Race, Capital Punishment, and the Supreme Court, 101 Harv L Rev 1388, 1419-21 (1988); Carter, 97 Yale L J at 420, 444 (cited in note 17$)$.

${ }^{37}$ See Part III.B. for a discussion of the "baseline" problem raised by such discriminatory evaluation.

${ }^{38}$ Compare Samuel R. Gross and Robert Mauro, Patterns of Death: An Analysis of Racial Disparities in Capital Sentencing and Homicide Victimization, 37 Stan L Rev 27, 106-09 (1984).
} 
clear, however, that a decision by a governmental actor effectuating or catering to private discrimination itself violates the Equal Protection Clause. ${ }^{39}$

Finally, we reach that most perplexing facet of $M c$ Cleskey-the relationship between the "intent" requirement and the use of statistical evidence. At bottom, McCleskey rests on the conclusion that even the sophisticated, multivariate regression analysis of the Baldus study is inadequate as a matter of law in this context to "prove" intentional discrimination in a particular case. McCleskey did not hold that statistical evidence is always insufficient to prove intent. Indeed, the Court acknowledged that in jury selection and employment discrimination cases, statistical evidence is regularly accepted as evidence of intent. But the Court distinguished the death penalty context primarily on the ground that the presence of substantial discretion in capital sentencing made reliance on statistical evidence inappropriate. ${ }^{40}$

The Court's reasoning reflects a profound misunderstanding of the nature of statistical evidence and of discretion. The existence of discretion does not mean that decisions are random or that they are not produced by guiding factors. If that is what discretion meant, then the death penalty would be generally unconstitutional under the Eighth Amendment. ${ }^{41}$ Discretion means that a decision is properly influenced by numerous, often incommensurate factors. Without a doubt, the presence of substantial discretion often makes it difficult to determine with precision the true causes of a decision. But isolating such causes is exactly what multivariate regression analysis does. The purpose of such analysis is to ferret out causation when direct evidence is lacking. Multivariate regression analysis seeks to determine the causal influence of a variety of factors, all of which are understood to have an impact on a final result. It achieves this by holding other variables constant, thus

${ }^{39} 466$ US 429, 433 (1984) (“[ $t$ ] he Constitution cannot control [private] prejudices but neither can it tolerate them. Private biases may be outside the reach of the law, but the law cannot, directly or indirectly, give them effect. 'Public officials sworn to uphold the Constitution may not avoid a constitutional duty by bowing to the hypothetical effects of private racial prejudice that they assume to be both widely and deeply held." (quoting Palmer v Thompson, 403 US 217, 260-261 (1971) (White, J, dissenting))); see note 31 and accompanying text.

${ }^{40}$ See McCleskey, 481 US at 292-97.

${ }^{4 t}$ See Furman v Georgia, 408 US 238 (1972). 
isolating the effects of the suspected variable. Of course, statistical evidence can never provide direct evidence of intent (or causation) in any particular case. And there is always the danger that any particular statistical analysis has left out an important causal variable, thereby undermining the validity of its results. No scientific study is any better than the methodology that produces it. But a careful analysis based on a well-formulated model can provide valid circumstantial evidence of causation. ${ }^{42}$

The statistical evidence of race-of-the-victim discrimination in the capital sentencing system is more than sufficient to establish causation. The Baldus study controlled for every relevant variable other than race, which is why the study is regarded as an exemplary piece of social science research..$^{43}$ Furthermore, as noted above, the results of the Baldus study have been replicated in a number of other sophisticated studies. Such consistency of results, across different data sets, different models, and different time periods, is more than sufficient to establish that race is a causal factor in the capital sentencing system.

Why, then, did the Court reject McCleskey's statistical challenge to the Georgia death penalty system? Though the majority opinion is somewhat opaque on this point, ${ }^{44}$ it seems to suggest that statistical evidence, no matter how powerful, cannot prove causation in a particular case; and the primary basis for this conclusion appears to have been concerns about the practical consequences of permitting statistical evidence to make out even a prima facie case of intentional discrimination:

[T]o prevail under the Equal Protection Clause, McCleskey must prove that the decisionmakers in bis case acted with dis-

\footnotetext{
${ }^{42}$ For an example of the relationship between causation and statistical evidence, consider the example of tobacco and lung cancer. Until recently, medical science had been unable to determine the direct chain of events between smoking cigarettes and developing lung cancer. See David Stout, Direct Link Found Between Smoking and Lung Cancer, New York Times A1 (Oct. 18, 1996) (reporting recent scientific study claiming to find first direct, causal link between smoking and lung cancer). In other words, scientists were unable to find direct evidence of causation. Nonetheless, there was overwhelming statistical evidence of the link between smoking and lung cancer, see The Health Consequences of Smoking: $A$ Report of the Surgeon General, 1982 6-42 (1982), and few respectable scientists (other than those working for tobacco companies) doubted that a causal link existed between the two.

${ }^{43}$ See note 5 .

4t The Court stated, "The unique nature of the decisions at issue in this case also counsels against adopting [an inference of discrimination] from the disparities indicated by the Baldus study." 481 US at 297. The Court declined to specify wbat that "unique nature" was.
} 
criminatory purpose. He offers no evidence specific to his own case that would support an inference that racial considerations played a part in his sentence. Instead, he relies solely on the Baldus study. McCleskey argues that the Baldus study compels an inference that his sentence rests on purposeful discrimination. McCleskey's claim that these statistics are sufficient proof of discrimination, without regard to the facts of a particular case, would extend to all capital cases in Georgia, at least where the victim was white and the defendant is black. ${ }^{45}$

There are several responses to the last sentence in this passage. First, the Court is simply wrong when it asserts that acceptance of the Baldus study would invalidate all capital sentences in Georgia "where the victim was white and the defendant is black." The Baldus study found that the race of the defendant was not an important variable in capital sentencing decisions. Not all black defendants convicted of killing white victims would be entitled to relief, and it is conceivable that some white defendants convicting of killing white victims might be entitled to relief. Second, McCleskey's claim works only in cases involving comparable levels of heinousness. The Baldus study found little divergence between white-victim cases and black-victim cases where the killings were especially aggravated or relatively unaggravated. Third, acceptance of the Baldus study does not require invalidation of all suspect sentences, it only creates a prima facie case against them. Prosecutors would remain able to rebut any inference of discrimination raised by statistical evidence, and so to save death sentences from invalidation. Finally, it is quite possible that under the Supreme Court's holding in Teague $v$ Lane, ${ }^{46}$ which postdated McCleskey by two years, a decision recognizing claims such as McCleskey's would not be applied retroactively on federal habeas review, so that only death sentences still on direct review, and of course future trials, would be affected.

The Court's response to its concerns over the effects of ruling for McCleskey was to paper over the issue of the requisite quantum of proof for McCleskey's equal protection claim. The Baldus study did not prove to a moral certainty or beyond a reasonable

\footnotetext{
45481 US at 292-93 (footnote omitted).

46489 US 288 (1989).
} 
doubt that race caused McCleskey's capital sentence. But constitutional claims ordinarily need be proven only by a preponderance of the evidence. Viewing the evidence in the light most favorable to McCleskey, which the Court was required to do, a reasonable finder of fact certainly could have concluded that racial factors more likely than not caused the prosecutor to seek the death penalty against McCleskey. The Court, however, apparently held McCleskey to a higher standard of proof than preponderance of the evidence. "Because discretion is essential to the criminal justice process, we would demand exceptionally clear proof before we would infer that the discretion has been abused," Justice Powell wrote. ${ }^{47}$ When the Court says that it will disturb prosecutorial decisions about the death penalty only upon "exceptionally clearproof" of discrimination, it is saying that prosecutors are free to discriminate against victims on the basis of their race as long as they do not advertise it by admitting to the discrimination or uttering racial epithets in public. This is a stunning message. Moreover, the Court has not accorded prosecutors that level of discretion in exercising peremptory challenges in criminal cases. A Batson claimant must prove intent to discriminate, but the Court has never suggested that such intent must be proved by "exceptionally clear" evidence.

Ultimately, McCleskey appears to rest on a misunderstanding of the statistical evidence provided by the Baldus study. The Court in McCleskey equated the regression analysis in that case with the simple racial correlations at issue in Davis, Arlington Heights, and Feeney. ${ }^{48}$ But there is a critical difference between the statistical evidence in McCleskey and the evidence in the earlier cases. By relying only on simple correlations to assert an equal protection challenge, none of the plaintiffs in the earlier cases had proved that race or gender was a cause of the challenged conduct, rather than some other causal factor which correlated with race or gender. In McCleskey, on the other hand, the Baldus study established that in a substantial number of capital cases, the same result would not have occurred but for the race of the victim, and that there was therefore a substantial probability that McCleskey's sentence

47481 US at 297.

${ }^{48}$ See notes $20-23$ and accompanying text. 
would not have been the same had the race of his victim been different. ${ }^{49}$

An account of the Court's misadventures with statistical evidence, however, tells only one story about McCleskey. In fact, there was more at work in McCleskey than a dispute over statistics, or a technical error by the Court. As almost every commentator has noted, McCleskey was clearly influenced by the Court's concerns about the practical and societal consequences of granting McCleskey relief. ${ }^{50}$ In particular, the Court was concerned that granting relief might undermine the criminal justice system by allowing great numbers of defendants to challenge their sentences. ${ }^{51}$ Moreover, one of the most intractible issues in McCleskey involved the precise nature of the equal protection claim. Relatively early in its opinion, the Court stated that McCleskey was not seeking to litigate the rights of victims who may have been discriminated against by the Georgia capital sentencing system..$^{52}$ As noted above, however, victim-based discrimination is the only form of discrimination in capital sentencing for which statistical analyses have presented strong evidence. This raises the question of the precise nature of the claim that McCleskey sought to raise and that the Court rejected. As Randall Kennedy notes, it became clear during oral argument in McCleskey that the justices were quite concerned about the justiciability issues raised by the interaction between a victimbased claim and a defendant claimant. But as he also notes, the

\footnotetext{
${ }^{49}$ There is a telling passage in Justice Powell's majority opinion. Toward the end of the discussion rejecting McCleskey's statistical evidence, the Court states that there is no reason to infer discriminatory intent from the Baldus study "because a legitimate and unchallenged explanation for the decision [to sentence McCleskey to death] is apparent from the record: McCleskey committed an act for which the United States Constitution and Georgia laws permit imposition of the death penalty." 481 US at 297. This statement suggests that the Court did not fully understand McCleskey's argument. The Baldus study proved that a large number of people in McCleskey's situation would not have been sentenced to death if their victims had been black. Every single one of these people had "committed an act for which the United States Constitution and Georgia laws permit imposition of the death penalty." That McCleskey was eligible for the death penalty did nothing to distinguish him from them, and therefore did nothing to negate the substantial probability that he would not have gotten the death penalty had his victim been black. To support its conclusion, the Court had to distinguish McCleskey from other "midrange" killers of black victims who did not receive the death penalty. It did not.

${ }^{50}$ See, e.g., Ortiz, 41 Stan L Rev at 1142-49 (cited in note 24); Kennedy, 101 Harv L Rev at 1413-15 (cited in note 5); Carter, 97 Yale LJ at 440-41 (cited in note 17); Selmi, 86 Georgetown L J at 320-23, 347 (cited in note 28).

${ }^{51}$ McCleskey, 481 US at 314-19.

${ }^{52} \mathrm{Id}$ at $292 \mathrm{n} 8$.
} 
opinions in the case failed to examine this issue. ${ }^{53}$ In the remainder of this article, we will explicate the complex relationships between race-of-victim discrimination and modern justiciability law, with a particular focus on the remedial alternatives open to legislatures and courts in responding to unconstitutional prosecutorial discrimination against black murder victims.

\section{Ascertaining the Nature of Equal Protection Violations}

In the previous section, we have tried to demonstrate that a prosecutor violates the Equal Protection Clause when he even unconsciously elects not to seek the death penalty because the victim is black or elects to seek the death penalty because the victim is white. But there remains the rather puzzling matter of crafting an appropriate remedy.

\section{A. OVERVALUATION AND UNDERVALUATION OF VICTIMS' LIVES}

The soundest approach to analyzing possible remedies for prosecutorial discrimination against victims on the basis of race is to divide such discrimination into two categories: (1) cases where the prosecutor seeks the death penalty because the prosecutor "overvalues" a white victim because of race, and (2) cases where the prosecutor chooses not to seek the death penalty because the prosecutor "undervalues" a black victim because of race. The following matrix illustrates the relationship between the nature of the constitutional violation and the party structure of the litigation.

\begin{tabular}{|l|c|c|}
\hline & Overvaluation & Undervaluation \\
\hline Defendants & Cell 1 & Cell 3 \\
\hline Victims' Families & Cell 2 & Cell 4 \\
\hline
\end{tabular}

This approach links the remedy with the nature of the equal protection violation. In theory, every equal protection case poses the problem of whether to "level up" or "level down." 54 If Group A

\footnotetext{
${ }^{53}$ Kennedy, 101 Harv L Rev at 1392 n 15 (cited in note 5).

${ }^{54}$ See Welsh v United States, 398 US 333, 361 (1970) (Harlan, J, concurring in result).
} 
is being treated worse than Group B for no constitutionally permissible reason, the court must decide whether to raise Group A to Group B's level or whether to lower Group B to Group A's level. (If the subject matter is amenable, the court might have the groups meet halfway.) But without some normative baseline, the choice between these remedies is arbitrary. As we explain later, in choosing a remedy, the Equal Protection Clause requires the court to ascertain how the governmental actor would have behaved had it not used the impermissible classification. ${ }^{55}$ On rare occasions, the governmental actor has already expressed its view of whether to level up or down if a court should find that the act violates equal protection. The court must respect this intent. Usually, however, the governmental actor has not considered what should happen if its act is held unconstitutional. In that case, the court must do its best to ascertain what the actor would have done had it not taken any impermissible consideration into account.

In the preceding matrix, the horizontal axis depicts the dichotomy between equal protection violations consisting of the overvaluation of white victims' lives versus those consisting of the undervaluation of black victims' lives. The vertical axis represents the two groups of litigants who might seek to challenge discrimination on the basis of the victim's race-first, defendants facing capital punishment for killing white victims; second, the families of black murder victims. In this matrix, we assume that all defendants facing capital punishment who challenge discrimination in favor of white victims seek to have their sentences commuted to life imprisonment - that is, to be treated in the same way as defendants who murder black victims. Presumably, they are uninterested in winning damages.

We conclude that the viable remedies for prosecutorial race discrimination against murder victims lie in Cells 1 and 4. A capital defendant should be able to seek commutation of his death sen-

\footnotetext{
${ }^{55}$ See notes 106-10 and accompanying text; Heckler $v$ Mathews, 465 US 728, 738-39 and n 5 (1984) (suggesting that if the legislature has indicated a preference regarding the proper remedy, courts should generally abide by that preference). See also People v Liberta, 474 NE 2d 567 (NY 1984), in which the New York Court of Appeals held that unmarried men were denied equal protection because, unlike married men, they could not rape their significant others with impunity. The court had two choices: extend rape law to married men or abolish it for unmarried men. The court stated that it was required to "discern what course the Legislature would have chosen to follow if it had foreseen our conclusions. . . ."
} 
tence when he proves that the prosecutor's overvaluation of his white victim's life constituted a "but-for" cause of the death sentence. The relatives of a black victim should be able to recover damages if they prove that the prosecutor's undervaluation of the victim's life was a "but-for" cause of the decision not to seek the death penalty. In the balance of this article we explain further our analytic framework and conclusions.

\section{B. PROVING OVERVALUATION AND UNDERVALUATION}

How can one tell whether a prosecutor has overvalued, undervalued, or properly valued a victim's life? How can one possibly know what a "correct" nonracial valuation would be in any particular case? We do not claim that there is an objectively correct valuation. Rather, the correct valuation is whatever the prosecutor would have decided had he been blind to the victim's race. If a prosecutor would have pursued the death penalty without knowing the victim's race, but declined to seek the death penalty knowing the victim was black, then he has undervalued the victim's life on the basis of race. If the prosecutor would have forgone the death penalty not knowing the victim's race, but sought it knowing the victim was white, then he has overvalued the victim's life. The "correct" valuation is a purely subjective matter.

How would a claimant prove an equal protection violation on either an overvaluation or undervaluation theory? The first step would be to ascertain a baseline. To do this, we must know two things: (1) the relevant aggravating and mitigating factors, and (2) the rate at which prosecutors seek the death penalty in cases with similar factors. We will refer to the first consideration as the "aggravation level" and the second as the "seek rate." The aggravation level for a particular case is determined by the application of an "aggravation index." The index consists of a list of factors correlating strongly with prosecutorial decisions to seek the death penalty. Each factor is assigned a value based on the strength of its correlation with decisions to seek capital punishment. The cumulation of these values produces an "aggravation level" for the case.

For illustrative purposes, we have reprinted a table from the Baldus study that could be used as a model aggravation index (see 
Table 1) ${ }^{56}$ Baldus explains that the "key measures of the impact of a given variable are the logistic-regression coefficient . . . and the odds multiplier, which is the antilog of the logistic-regression coefficient." ${ }^{57}$ The higher the odds multiplier or logistic-regression coefficient, the greater the influence on the capital sentencing decision. The variables present in any particular case are combined to produce an overall aggravation level. Next, cases are grouped according to aggravation levels and it is determined how often prosecutors seek the death penalty for that particular aggravation range. We have also reprinted a graph from the Baldus study showing the relationship between aggravation levels and the corresponding death sentencing rates (see Fig. 1). Because our proposal covers prosecutorial discrimination only, we would substitute seek rates for actual death sentencing rates.

Consider the following hypothetical. The prosecutor seeks the death penalty in a case in which the defendant murdered a white person under factual circumstances that place the case at 0.48 on the aggravation index. The seek rate for cases in this range is 26 percent. This means that in 74 percent of aggravation-comparable cases cutting across race, prosecutors do not seek the death penalty.

We already have enough information to question the prosecutor's decision. The aggravation index is drawn from the Baldus study's thirty-nine-variable model ${ }^{58}$ which already has taken into account the most significant reasons why a prosecutor would or

\footnotetext{
${ }^{56}$ The Baldus study covered only Georgia. Because of peculiarities in the capital sentencing systems of individual states, challenges to capital sentencing would have to be based on statistical studies specific to those states. Several such studies have already been conducted. See, e.g., Michael L. Radelet and Glenn L Pierce, Choosing Those Who Will Die: Race and the Death Penalty in Florida, 43 Fla L Rev 1 (1991); Thomas J. Keil and Gennaro F. Vito, Race and the Deatb Penalty in Kentucky Murder Trials: 1976-1991: A Study of Racial Bias as a Factor in Capital Sentencing, http://dpa.state.ky.us/ rwheeler/archives/race/vito.txt (1995); but see Stephen P. Klein and John E. Rolph, Relationship of Offender and Victim Race to Death Penalty Sentences in California, 32 Jurimet J 33 (1991) (finding no statistically significant racial discrimination in the imposition of the death penalty in California).

${ }^{57}$ Baldus, Woodworth, and Pulaski, supra, Equal fustice and the Death Penalty at 71 n 34 (cited in note 7).

${ }^{58}$ The model contains thirty-nine nonracial variables plus the race of the defendant and the race of the victim. The race of the defendant was found not to exert much influence on the capital sentencing process; the race of the victim was found to exert great influence. Baldus, Woodworth, and Pulaski, Equal Fustice and the Deatb Penalty at 319 (Table 52) (cited in note 7).
} 


\section{TABLE 1}

Logistig-Regression Coefficients, Estimated for Selected Aggravating and Mitigating Factors and the Race of Victim and Defendant in an Analysis of Death-Sentencing Outcomes, CSS

\begin{tabular}{|c|c|c|}
\hline Variable Label and Name & $\begin{array}{l}\text { Death- } \\
\text { Odds } \\
\text { Multiplier }\end{array}$ & $\begin{array}{l}\text { Adjusted Logistic } \\
\text { Regression Coefficient } \\
\text { (with Level of } \\
\text { Statistical Significance) }\end{array}$ \\
\hline 1. Defendant was not the triggerman (NокILL) & .06 & $-2.75(.0001)$ \\
\hline $\begin{array}{l}\text { 2. Defendant admitted guilt and no defense as- } \\
\text { serted (DEFADMIT) }\end{array}$ & .28 & $-1.27(.12)$ \\
\hline $\begin{array}{l}\text { 3. Defendant had a history of drug or alcohol } \\
\text { abuse (DRGHIs) }\end{array}$ & .36 & $-1.01(.007)$ \\
\hline 4. Defendant was under 17 years of age (sмyouth) & .41 & $-.88(.23)$ \\
\hline 5. Jealousy motive (JEALOUS) & .47 & $-.74(.53)$ \\
\hline $\begin{array}{l}\text { 6. Family, lover, liquor, or barroom quarrel } \\
\text { (BLVICMOD) }\end{array}$ & .54 & $-.61(.15)$ \\
\hline $\begin{array}{l}\text { 7. Defendant was retired, student, juvenile, house- } \\
\text { wife (MITDEFN) }\end{array}$ & .54 & $-.61(.64)$ \\
\hline 8. Hate motive (HATE) & .71 & $-.34(.69)$ \\
\hline 9. Pecuniary gain motive for self/other (LDFB 4$)^{\star}$ & .80 & $-.22(.70)$ \\
\hline 10. Defendant was black (BLACKD) & .94 & $-.06(.88)$ \\
\hline $\begin{array}{l}\text { 11. Number of prior defendant felony prison terms } \\
\text { (PRISONx) }\end{array}$ & 1.1 & $.08(.67)$ \\
\hline $\begin{array}{l}\text { 12. Defendant caused death risk in public place to } 2 \\
\text { or more people (LDFB } 3 \text { ) }\end{array}$ & 1.1 & $.14(.74)$ \\
\hline 13. One or more coperpetrators involved (COPERP) & 1.3 & $.24(.56)$ \\
\hline 14. Defendant was a female (FEMDEF) & 1.3 & $.28(.70)$ \\
\hline $\begin{array}{l}\text { 15. One or more convictions for a violent personal } \\
\text { crime, burglary, or arson (VPCARBR) }\end{array}$ & 1.35 & $.30(.53)$ \\
\hline $\begin{array}{l}\text { 16. Nonproperty-related contemporaneous crime } \\
\text { (NONPROPC) }\end{array}$ & 1.4 & $.35(.64)$ \\
\hline $\begin{array}{l}\text { 17. Killing to avoid, stop arrest of self, other } \\
\text { (LDFB 10) }\end{array}$ & 1.5 & $.41(.32)$ \\
\hline $\begin{array}{l}\text { 18. Victim was a police or corrections officer on } \\
\text { duty (LDFB8) }\end{array}$ & 1.7 & $.52(.58)$ \\
\hline $\begin{array}{l}\text { 19. Defendant primary mover in planning homicide } \\
\text { or contemporaneous offense (DLEADER) }\end{array}$ & 1.7 & $.55(.33)$ \\
\hline $\begin{array}{l}\text { 20. Rape/armed robbery/kidnapping plus silence wit- } \\
\text { ness, execution, or victim pleaded for life } \\
(\mathrm{LDFB} 7 \mathrm{D})\end{array}$ & 1.8 & $.60(.16)$ \\
\hline $\begin{array}{l}\text { 21. Coperpetrator received a lesser sentence } \\
\text { (CPLEsSEN) }\end{array}$ & 2.2 & $.78(.09)$ \\
\hline 22. Multiple shots (MULSH) & 2.2 & $.79(.04)$ \\
\hline 23. Victim was drowned (DRown) & 2.6 & $.96(.24)$ \\
\hline 24. Victim was a stranger (STRANGER) & 2.8 & $1.03(.01)$ \\
\hline 25. Victim bedridden/handicapped (VBED) & 2.8 & $1.04(.33)$ \\
\hline 26. Kidnapping involved (KIDNAP) & 2.9 & $1.06(.17)$ \\
\hline
\end{tabular}


TABLE 1 (Continued)

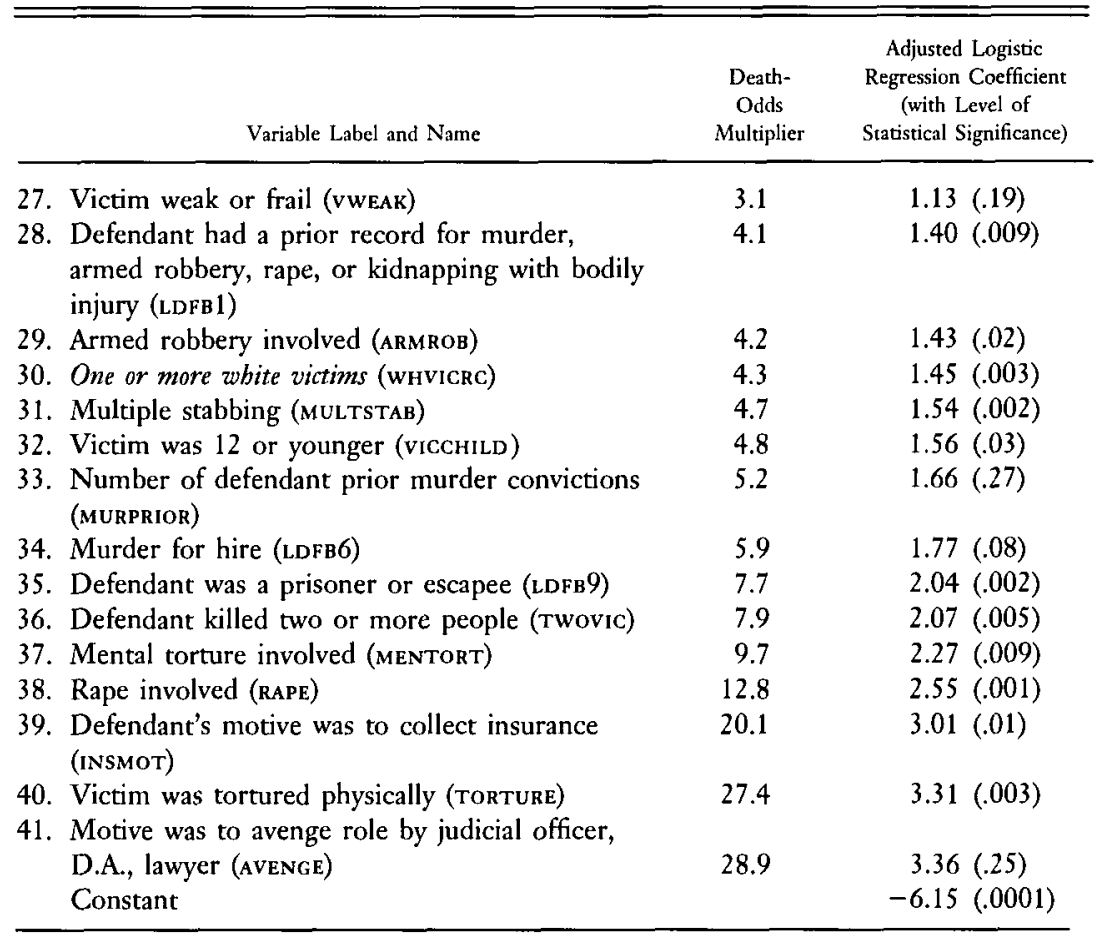

Source._From David C. Baldus, George Woodworth, and Charles A. Pulaski, Jr., Equal Justice and the Deatb Penalty: A Legal and Empirical Analysis 321 (fig. 32) (1990).

Note. - The table reports the odds multiplier and coefficients for the race-of-defendant and the race-of-victim variables in the thirty-nine-variable core model. The outcome variable was Dsentals, coded: $1=$ Death Sentence, $0=$ Other Sentence.

* The negative sign of the coefficient for LDFB4 (pecuniary gain motive) is perverse. We attribute the sign of LDFB4 to its correlation with the variable for armed robbery (АRмRов).

would not seek the death penalty. Knowing the aggravation level, but without knowing the race of his victim, we would predict that the prosecutor would not seek the death penalty. When it is revealed that the prosecutor sought capital punishment, and that the victim was white, we have good reason to suspect that race played a proximate role in the decision.

Why do our suspicions gravitate toward race? We look first to race because the Baldus study strongly indicates that the race of the victim exerts a high degree of influence on the capital sentencing process in the midrange-aggravation cases. When the case involves one or more white victims, the odds of receiving a death 


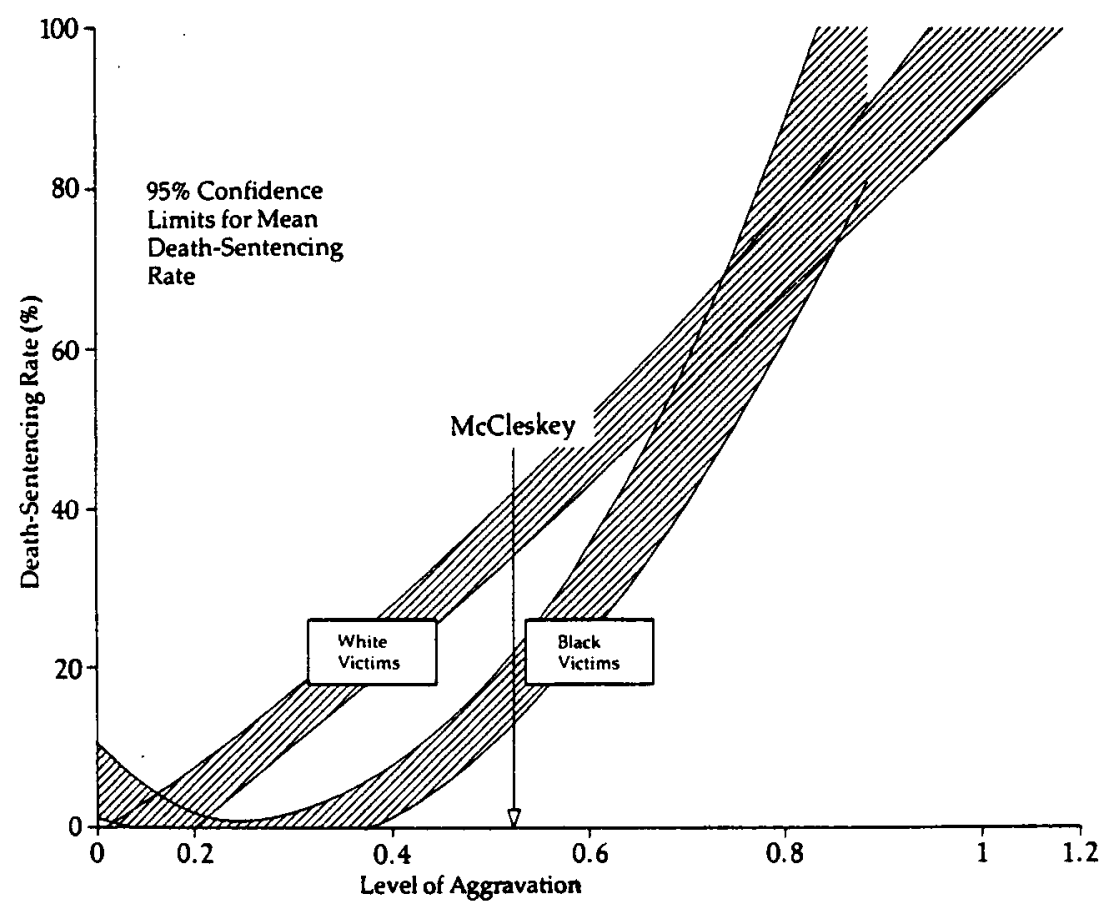

FIg. 1.-Black defendant model, Georgia Charging and Sentencing Study, 1973-1979. (From David C. Baldus, George Woodworth, and Charles A. Pulaski, Jr., Equal fustice and the Death Penalty: A Legal and Empirical Analysis 321 (Fig. 32) (1990).)

sentence are multiplied on average by a magnitude of $4.3 .{ }^{59}$ As Justice Brennan pointed out in his McCleskey dissent, this puts the influence of the victim's race virtually on a par with the influence of multiple stabbing, a serious prior criminal record, or involvement in an armed robbery. ${ }^{60}$ Because the race of the victim is so influential, and because it is not taken into account in the aggravation index, while all other, properly relevant factors are, our suspicions naturally turn to that factor.

This reason for suspecting race can be illustrated in another way. Consider the differential between seek rates for cases involving white and black victims. The average seek rate for white-victim

${ }^{59}$ This odds multiplier cuts across all aggravation levels. The odds multiplier at McCleskey's specific aggravation level is closer to 2.2 (37 percent divided by 17 percent). See note 62 and accompanying text.

${ }^{60} 481$ US at 326 (Brennan, J, dissenting). 
cases in the 0.4 to 0.6 range is 37 percent. The average seek rate for black-victim cases in the same range is 17 percent. ${ }^{61}$ Prosecutors are more than twice as likely to seek the death penalty in a white-victim case in this range as in a black-victim case, even after controlling for the aggravation of the offense. Something has to explain a discrepancy that large, and race is the leading candidate. At this point it is critical to emphasize what we have not said. We have not claimed that the statistics prove race discrimination in this particular case. Rather, we claim that the statistics create a strong suspicion of race discrimination-specifically, an overvaluation of the white victim's life. ${ }^{62}$ This statistical showing should make out a prima facie case under the Equal Protection Clause. Because the defendant has shown that prosecutors in most aggravation-comparable cases do not seek the death penalty, he has shown that, more likely than not, race discrimination "caused" the decision to seek the death penalty. The burden should now shift to the prosecutor to offer a legitimate, persuasive nonracial rationale for seeking the death penalty. ${ }^{63}$ This burden-shifting scheme is virtually identical to what the Court has adopted in jury discrimination challenges under Batson $v$ Kentucky ${ }^{64}$ and in disparate treatment cases under Title VII.$^{65}$

Once the judge has decided that the claimant has established a prima facie case, the prosecutor may discharge his burden by giv-

${ }^{61}$ Recall that we have fictitiously substituted seek rate for death-sentencing rate in the Baldus graph.

${ }^{62}$ Similarly, to prove undervaluation of a black victim's life a claimant must show that in similar-aggravation cases, most prosecutors would seek the death penalty if the victim were white.

${ }^{63}$ Before considering how the prosecutor might rebut such a prima facie case, we pause to consider how large a differential must exist between seek rates for murderers of whites and murderers of blacks. In our hypothetical case, the difference was drarnatic-more than 2 to 1 . In such circumstances, the claimant has clearly made out a prima facie case. Suppose, however, that the differential was much smaller. Suppose it was 19 percent to 17 percent. Has the claimant still made out a prima facie case? The answer depends on two factors. One is the size of the relevant statistical universe; the other is the quality of the research methodology. If the number of death-eligible defendants in the jurisdiction is extremely large, and if the research methodology is impeccable, a difference of 19 percent to 17 percent could establish a prima facie case. The issue is no different than in other cases involving statistical proof.

${ }^{64} 476$ US 79 (1986). See also Purkett v Elem, 514 US 765 (1995) (in order to rebut prima facie case, prosecutor need not articulate plausible nonracial explanation for using strike, but only facially nonracial explanation).

${ }^{65}$ See McDonnell Douglas Corp. v Green, 411 US 792 (1973); Texas Dept. of Community Affairs v Burdine, 450 US 248 (1981). 
ing any number of explanations. Perhaps the prosecutor had a close relative who died under similar circumstances. Perhaps the defendant was a member of a particularly vicious gang. Perhaps the prosecutor needed to seek the death penalty in this case to get re-elected. All of these rationales go beyond the factors examined in the Baldus study and might satisfactorily explain why the prosecutor sought the death penalty in this particular case, without regard to race.

In many (if not most) cases, however, the prosecutor will be unwilling or unable to point to a specific factor outside the Baldus study. A prosecutor may simply say that he sought the death penalty because the defendant had committed a heinous murder. Other prosecutors might not find it heinous, but that is not the issue. The prosecutor in this case found it heinous, and that is not a racial reason for seeking the death penalty.

If it is so easy for a prosecutor to articulate a nonracial rationale for seeking the death penalty, then what good is it to afford the claimant a cause of action? The answer is that the prosecutor's proffer must be credible. The judge must be persuaded that the prosecutor has not simply conjured up an after-the-fact rationalization for the decision. The multivariate analysis may not prove what this particular prosecutor thinks about the heinousness of the facts of this particular case, but it does tell us what most prosecutors think about it. And, unless there is a special reason to think that this prosecutor regards heinousness quite differently than other prosecutors, the judge is entitled to find that the proffered rationale lacks credibility.

Moreover, once the prosecutor has articulated a nonracial rationale for seeking (or forgoing) the death penalty, the claimant now has the opportunity to show that the proffered rationale is a pretext for discrimination. Notice that in this context, a "pretext" may be one that the prosecutor has offered in good faith, unaware of his own unconscious racism. The claimant's burden of demonstrating pretext now "merges" with his or her ultimate burden of persuading the trier of fact that, more likely than not, the prosecutor discriminated on the basis of race. ${ }^{66}$ The claimant is entitled to discovery of the prosecutor's prior record in cases where the facts would have supported the death penalty. The claimant may intro-

${ }^{66}$ Compare Texas Department of Community Affairs v Burdine, 450 US 248 (1981). 
duce evidence that the prosecutor has a pattern and practice of seeking the death penalty in cases where the victim is white, but not where the victim is black. ${ }^{67}$ Even if a particular prosecutor has no record at all in capital cases, the judge is entitled to find the prosecutor's proffer noncredible. ${ }^{68}$

In the real world, judges may tend to accept prosecutors' stated rationales. This appears to have happened with Batson ${ }^{69}$ But even if this happens, there is considerable value in requiring prosecutors to articulate their reasons. As noted earlier, many prosecutorial decisions about capital sentencing appear to be influenced by unconscious racial thinking. The very existence of a capital sentencing remedy may lead prosecutors to think more carefully about why they do and do not seek the death penalty in particular cases.

\section{Remedies and Justiciability}

In this section, we will individually analyze the possibility of a successful claim, and the remedial possibilities, in each of the four cells of our proposed "matrix." 70

\section{A. OVERVALUATION OF WHITE VICTIMS-DEFENDANT SEEKS COMMUTATION}

In Cell 1, the defendant argues that he was sentenced to death because his victim was white. He argues that he would not have been sentenced to death if the prosecutor had valued the victim's

\footnotetext{
${ }^{67}$ Although most prosecutors have not actually sought the death penalty in a large number of cases, that is not the relevant comparison pool. The relevant pool consists of all cases in which the defendant was indicted for (or perhaps merely committed) a crime that would have supported the death penalty. This includes cases where the prosecutor ultimately reduced the charges to voluntary manslaughter or decided to settle for life imprisonment on a murder conviction. This is a much larger pool of cases, and will often stand ready to contradict a prosecutor's fabricated rationale for seeking the death penalty.

${ }^{68}$ Unless the prosecutor has utterly failed to articulate a nonracial rationale, the ultimate burden of persuasion always rests on the claimant. Cf. St. Mary's Honor Center v Hicks, 509 US 502 (1993) (claimant retained burden of persuasion even where trial judge found defendant's proffer of legitimate reasons implausible). We do not necessarily endorse Hicks. We simply think there is no reason to treat this issue any differently in the capital sentencing context than in the disparate treatment context of Title VII.

${ }^{69}$ See Susan H. Herman, Why the Court Loves Batson: Representation-Reinforcement, Colorblindness, and the fury, 67 Tulane L Rev 1807, 1830 n 93 (1993) ("overcoming the raceneutral explanation hurdle has not been that difficult") (citing examples).

${ }^{70}$ See text display (page 127).
} 
life "properly." Assuming the defendant can prove this claim, he still faces two doctrinal obstacles-first, that he may lack standing; second, even if the prosecutor did consider the victim's race, this may not make out a constitutional claim in favor of a defendant.

1. Standing. The Supreme Court has held that the "case or controversy" requirement of Article III imposes three requirements on any litigant who wishes to assert rights in federal court. First, the litigant must have suffered particularized "injury-in-fact." 71 That is, the litigant must have suffered a tangible harm not common to all of society. ${ }^{72}$ Second, the defendant's conduct must have actually caused the injury. ${ }^{73}$ Third, the litigant must seek relief that would redress the injury. ${ }^{74}$ In addition to these constitutional requisites of standing, the Court has held that the litigant generally must assert his own rights and that he is generally prohibited from asserting the rights of third parties. ${ }^{75}$

The defendant who claims that his victim's life has been overvalued has no difficulty with the injury-in-fact requirement. His injury is the sentence of death. He also satisfies the causation requirement because the overvaluation of the white victim's life is a but-for cause of the death sentence. And redressability poses no problem because the injury (the death sentence) would be fully redressed by the requested relief (commutation).

The tricky question concerns the prohibition against third-party standing. If we focus on the inequality between white and black victims, the rule against third-party standing would apply. The prosecutor has overvalued the lives of white victims, which violates the right of black victims to equal protection of the laws. Yet this violates no right of the defendant. On the other hand, if we focus on the inequality between the killers of white people and the killers of black people, the rule against third-party standing does not

\footnotetext{
"See Sierra Club v Morton, 405 US 727 (1972).

${ }^{72}$ See Frothingham v Mellon, 262 US 447 (1923); Schlesinger $v$ Reservists Comm. to Stop the War, 418 US 208 (1974).

${ }^{73}$ See Linda R.S. v Richard D., 410 US 614 (1973); Warth v Seldin, 422 US 490 (1975); Simon v Eastern Kentucky Welfare Rights Org., 426 US 26 (1976).

${ }^{74} \mathrm{Id}$.

${ }^{75}$ Tileston v Ullman, 318 US 44 (1943) (per curiam); McGowan v Maryland, 366 US 420 (1961). The Supreme Court has created one other standing requirement not relevant here. In cases brought under the Administrative Procedure Act, the litigant must fall within the "zone of interests" that Congress sought to protect when it enacted the statute in question. See Assn of Data Processing Service Organizations, Inc. v Camp, 397 US 150 (1970).
} 
apply. By overvaluing the lives of white victims, the government treats killers of whites differently than the killers of blacks. This denies killers of whites equal protection of the laws.

In McCleskey, the Court assumed that the murderer of a white person has first-party standing to seek commutation of his death sentence, but its treatment of this issue was relegated to a footnote:

Although McCleskey has standing to claim that he suffers discrimination because of his own race, the State argues that he has no standing to contend that he was discriminated against on the basis of his victim's race. While it is true that we are reluctant to recognize "standing to assert the rights of third persons," . . . this does not appear to be the nature of McCleskey's claim. He does not seek to assert some right of his victim, or the rights of black murder victims in general. Rather, McCleskey argues that application of the State's statute has created a classification that is "an irrational exercise of governmental power," . . . because it is not "necessary to the accomplishment of some permissible state objective." . . . It would violate the Equal Protection Clause for a State to base enforcement of its criminal laws on "an unjustifiable standard such as race, religion, or other arbitrary classification." .. . Because McCleskey raises such a claim, he has standing. ${ }^{76}$

It is worth pausing a moment to digest what the Court has said here. It distinguishes between two types of equal protection claims: race-based classifications in particular, and arbitrary classifications in general. If McCleskey had tried to assert the rights of victims not to be discriminated against because of their race, he would confront the Court's prohibition against third-party standing. But (according to the Court) he made no such claim; he instead claimed that race discrimination against victims constituted an arbitrary classification in the enforcement of the criminal law. Thus, McCleskey did not seek to assert the right of victims not to be discriminated against on the basis of race, but his own right not to have the criminal law enforced against him on the basis of an arbitrary classification. ${ }^{77}$ But could he have raised the rights of black victims?

\footnotetext{
${ }^{76}$ McCleskey $v$ Kemp, 481 US at 291-92 n 8.

${ }^{77}$ Compare Henry P. Monaghan, Overbreadth, 1981 Supreme Court Review 1 (litigants are always permitted to challenge the validity of rules pursuant to which they are sanctioned).
} 
If the prohibition against third-party standing were absolute, one in McCleskey's position clearly would be unable to assert the rights of victims. But the Court has recognized three exceptions to the general prohibition. First, if a statute is "substantially overbroad," defendants whose conduct is unprotected may nonetheless assert the First Amendment rights of third persons whose protected conduct would fall within the challenged statute. ${ }^{78}$ Second, a claimant may assert the rights of third parties who are unable to assert their own rights if the claimant would represent the holders of the rights adequately. For example, in Barrows $v$ fackson ${ }^{79}$ a white vendor sold land to a black family in violation of a racially restrictive covenant. Other parties to the covenant sued the vendor for damages. The vendor was permitted to defend on the ground that enforcement would violate the black family's right to equal protection. The buyers, not being parties to the covenant, had no procedural vehicle to assert their rights. Third, the Court on occasion has permitted claimants to assert the rights of those with whom they have some sort of a relationship. For example, in Craig $v$ Boren, ${ }^{80}$ Oklahoma had prohibited sales of 3.2 percent beer to males under twenty-one and females under eighteen. A beer vendor challenged the law on the ground that it violated the equal protection rights of males between the ages of eighteen and twenty-one. The Supreme Court recognized the vendor's standing to assert "those concomitant rights of third parties that would be 'diluted or adversely affected' should [the] constitutional challenge fail and the statutes remain in force." 81 Similarly, in Powers $v$ Obio, ${ }^{82}$ a white criminal defendant challenged a prosecutor's use of peremptory challeges against black prospective jurors. The Court found that he had standing to assert the equal protection rights of these prospective jurors because such discrimination "places the fairness of a criminal proceeding in doubt" and because the rela-

\footnotetext{
${ }^{78}$ See Broadrick v Oklaboma, 413 US 601 (1973) (overbreadth must be "substantial"); Thornbill $v$ Alabama, 310 US 88 (1940 (creating overbreadth exception).

${ }^{79} 346$ US 249 (1953). See also NAACP $v$ Alabama, 357 US 449 (1958) (permitting NAACP to assert its members' rights not to disclose their identities).

${ }^{80} 429$ US 190 (1976).

${ }^{81}$ Id at 194.

82499 US 400 (1991).
} 
tionship between the defendant and the jurors "continues throughout the entire trial." ${ }^{83}$ Moreover, the prospective jurors had no ready means to challenge their own exclusion.

Does McCleskey fit any of these exceptions? In part, the answer depends on whether the families of black victims may sue prosecutors or their employers and vindicate their rights. If so, they need not rely on condemned murderers to assert the equal protection rights of black victims. Under present doctrine, however, it is not clear whether they would succeed in such actions. ${ }^{84}$ Assuming that such lawsuits are barred, a person in McCleskey's situation should have standing to assert the rights of black victims. There can be no doubt that the condemned "will be a motivated, effective advocate" for the black victim's equal protection rights. ${ }^{85}$ His life depends on it. And, as in Powers, the overvaluation of the lives of white victims "places the fairness of a criminal proceeding in doubt." 86 Although the relationship between a condemned killer of a white person and the family of a black victim may not go any deeper than their common interest in vindicating equal protection rights, the Court has several times permitted third-party standing on the basis of less than profound relationships. In Craig, the beer vendor presumably had no personal relationship with males between eighteen and twenty-one, since they could not legally purchase beer. In Powers, the criminal defendant and the excluded venireperson had never before met, and their common interest was limited to eradicating race discrimination from that single judicial proceeding. In Buchanan $v$ Warley, the Court even permitted a litigant to assert the rights of someone with whom he had an antagonistic relationship. ${ }^{87} \mathrm{~A}$ white seller of land sued the black purchaser for specific performance. The purchaser defended on the ground that a racially restrictive ordinance prohibited him from living in the house. The Supreme Court permitted the white plaintiff to assert the defendant's right not to be discriminated against on the basis of race, even though the defendant obviously wished not to

\footnotetext{
${ }^{83}$ Id at $411,413$.

${ }^{84}$ See Part IV.D.

${ }^{85}$ Powers, 499 US at 414.

${ }^{86}$ Id at 411.

${ }^{87} 245$ US 60 (1917).
} 
assert the right. McCleskey's basis for third-party standing was at least as strong as in these cases.

2. The appropriate standard of review. We thus conclude that a killer of a white, such as McCleskey, who is able to prove that the prosecutor overvalued the life of his white victim and that if his victim had been black he would not have received the death penalty, clearly has first-party standing to challenge his capital sentence directly; and probably he also has third-party standing to raise the rights of black victims who have been discriminated against by his prosecutor's actions. At this point, the constitutional standard of review becomes critical. What standard should govern overvaluation claims brought by defendants-strict scrutiny or simple rationality? The answer is intertwined with the standing analysis discussed above. If a defendant such as McCleskey were granted third-party standing to raise the claims of black victims, then the standard of review would of course be strict scrutinyand the defendant would almost certainly succeed in obtaining commutation, since the Court has not upheld a racial classification under strict scrutiny analysis since its infamous Korematsu decision. ${ }^{88}$ We have concluded that someone in McCleskey's position may assert such third-party standing.

Assuming for the sake of analysis that we are wrong in this conclusion, and that McCleskey had standing to assert only his own Fourteenth Amendment right not to be convicted on the basis of an arbitrary classification (which was the only claim, remember, that McCleskey himself raised), a difficult question arises. The defendant's death sentence is the product of an arbitrary, racial classification, but based on his victim's race, not his own. What is the appropriate constitutional standard of review for such a claim?

The question of what standard of review should apply to an equal protection claim in which the claimant is disadvantaged because of a classification based on the race of another person appears to remain open in the Supreme Court. The issue arose in the Court's recent decision in Miller $v$ Albright, ${ }^{89}$ but remained unresolved by the Court as a whole. Miller involved an equal protec-

${ }^{88}$ Korematsu v United States, 323 US 214 (1944) (upholding internment of JapaneseAmericans during World War II); see also Hirabayasbi v United States, 320 US 81 (1943).

${ }^{89} 118$ S Ct 1428 (1998). 
tion challenge brought by the illegitimate, foreign-born daughter of a U.S. citizen father against a federal statute that made it easier for the illegitimate, foreign-born children of American women to claim U.S. citizenship than the foreign-born children of American men. The plaintiff thus challenged a gender-based statute that disadvantaged her because of the gender of a third person, her father, rather than on her own gender. ${ }^{90} \mathrm{~A}$ highly fractured Court rejected her claim on a variety of grounds, several of which were unrelated to the issue at hand..$^{91}$ In a concurring opinion, however, Justice O'Connor, joined by Justice Kennedy, found that the plaintiff lacked third-party standing to raise her father's equal protection rights, and that her claim was therefore subject only to rational basis review. ${ }^{92}$ If O'Connor's analysis is correct, then an equal protection challenge by a capital defendant to victim-based discrimination would also be subject only to rational basis review, absent third-party standing. In a dissenting opinion, Justice Breyer, joined by Justices Souter and Ginsburg, questioned this aspect of Justice O'Connor's reasoning, ${ }^{93}$ but neither Justice O'Connor nor Justice Breyer cited any pertinent authority for their position, and the Court as a whole found it unnecessary to resolve the issue.

Lower court authority on this question is sparse. In a few early cases, courts granted first-party standing to developers suing municipalities alleged to have intentionally excluded minority tenants. The courts in these cases applied heightened scrutiny, suggesting

\footnotetext{
${ }^{90}$ Gender is considered a "semi-suspect" classification under the Equal Protection Clause, and therefore gender-based classifications are subject to "heightened" scrutiny (though not quite as heightened as the "strict" scrutiny to which race-based classifications are subject). See, e.g., United States v Virginia, 518 US 515 (1996).

${ }^{91}$ In particular, the plurality opinion by Justice Stevens (joined by Chief Justice Rehnquist) granted Miller third-party standing to raise her father's clains, but found that the statute survived heightened scrutiny, $118 \mathrm{~S} \mathrm{Ct}$ at $1436-42$; while a concurring opinion by Justice Scalia, joined by Justice Thomas, reasoned that, for reasons relating to the separation of powers, the Court lacked authority to grant Miller the relief that she requested, which was U.S. citizenship, id at 1446-49.

${ }^{92} \mathrm{Id}$ at 1445 (O'Connor, J, concurring in the judgment). Justices O'Connor and Kennedy provided the fifth and sixth votes for the result.

${ }^{43}$ Justice Breyer did not provide any support for his suggestion that Miller's claim should be subject to heightened scrutiny other than a rather weak analogy to laws that discriminate based on racial or religious ancestry. The analogy is poor because racial identity is of course alınost by definition transmitted to descendants, and even "religious ancestry" is often transmitted in the sense that children often adopt the faiths of their parents. "Gender ancestry," however, is a meaningless concept, since we all have the same "gender ancestry"-one man, one woman (at least for now).
} 
that the challenged classification does not have to be based on a claimant's own race. ${ }^{94}$ More recently, courts in analogous situations (primarily challenges brought by employers and general contractors to government-imposed affirmative action requirements) have tended to find third-party standing on the part of claimants seeking to raise the rights of others, and therefore have not considered the applicable standard of review absent such standing. ${ }^{95}$ Finally, in a handful of recent decisions, some courts have suggested, without explanation, that the identity of the discrimination victim alleged does affect the standard of review (i.e., the O'Connor position) by denying third-party standing and then applying deferential review to equal protection claims; but again, courts have failed to directly address the difficult standard-of-review question. ${ }^{96}$

The proper standard of scrutiny for a defendant's challenge to victim-based discrimination thus remains unresolved. But it is our view that Justice O'Connor's conclusion in Miller is probably "correct," in the sense that it is more consistent with the modern Court's approaches to standing and equal protection issues, and so better predicts the Court's likely resolution of this question (leaving aside the question of whether we agree with those approaches; we do not). In particular, it is clear that in recent years the Court's understanding of the nature of the equal protection right has shifted dramatically from a group-based vision to an extremely individualized approach. That understanding is plainly more consistent with a regime where strict scrutiny may be invoked only by claimants who can show that they were treated differently because of their race (or other suspect characteristic). ${ }^{97}$

\footnotetext{
${ }^{94}$ See G.T. Scott v Greenville County, 716 F2d 1409 (4th Cir 1983); Des Vergnes v Seekonk Water District, 601 F2d 9, 17 (1st Cir 1979); Park View Heigbts Corp. v City of Black Jack, 467 F2d 1208 (8th Cir 1972).

${ }^{95}$ See, e.g., Lutheran Church-Missouri Synod v FCC, 141 F3d 344 (DC Cir 1998) (FCClicensed radio station may challenge FCC rule requiring licensees to engage in affirmative action hiring, by raising the rights of potential applicants); compare Monterey Mechanical Co. $v$ Wilson, $125 \mathrm{~F} 3 \mathrm{~d} 702,707-08$ (9th Cir 1997) (finding first-party standing for a general contractor to challenge a requirement of hiring minority subcontractors, but imposing heightened scrutiny only because the plaintiff was disadvantaged vis-à-vis other general contractors who were woman- or minority-owned).

${ }^{96}$ See, e.g., Ablang v Reno, 52 F3d 801, 804-05 and n 4 (9th Cir 1995); Alexander $v$ Whitman, 114 F3d 1392, 1400-02, 1407-08 (3rd Cir 1997).

${ }^{97}$ To explain briefly, if the equal protection right is understood as a group-based right, then any member of a group may properly raise an equal protection claim and invoke heightened scrutiny so long as there is injury-in-fact (which of course is not a concern when a defendant seeks to commute a death sentence). Under this view, any black defendant
} 
The counterargument would be that any official use of race should trigger strict scrutiny, even if the claimant herself has not been discriminated against; but this position does not accord well with the modern Court's view that the Equal Protection Clause's primary effect is to protect individuals against being treated differently because of their race, ${ }^{98}$ and finds little support in recent case law. Therefore, it is probably true that under current equal protection jurisprudence, challenges to classifications based on the suspect characteristics of others are only subject to rational basis review.

Of course, concluding that more deferential scrutiny should apply does not necessarily resolve the question of whether a claim such as McCleskey's should prevail. Indeed, one can imagine an argument that any use of a racial classification within the criminal justice system, no matter how indirect, is so irrational and unacceptable that it should be struck down under any standard of scrutiny. But it is quite unlikely that such an argument would prevail under current standards, and indeed McCleskey might be fairly read to reject it. The reasons for this are somewhat counterintuitive, but follow from the nature of a standard of review. The crucial consequence of subjecting a governmental classification to "strict scrutiny" is that the classification then becomes presumptively un-

should be able to invoke strict scrutiny to challenge a racially biased capital sentencing system, even one tainted only by victim discrimination, but white defendants would not. If, however, the right is an individual one, then it would seem that only a person who is discriminated against because of his own suspect characteristic may invoke heightened equal protection scrutiny. At the time McCleskey was decided, the Court had not given much attention to this dichotomy - wbicb perhaps explains the ambiguity of the Court's standing discussion in McCleskey. The same ambiguity is demonstated in the Court's decision just one term earlier in Batson v Kentucky, 476 US 79 (1986), where the Court permitted a criminal defendant to challenge race-based peremptory challenges employed by prosecutors against jurors, without any discussion of standing. Later cases in the Batson line, however, clearly understand the Batson right as belonging to the juror who has been discriminated against on the basis of her race, which litigants are awarded third-party standing to invoke. See, e.g., Powers v Obio, 490 US 400 (1991) (white defendant has third-party standing to raise equal-protection rights of dismissed black jurors); Campbell $v$ Louisiana, $118 \mathrm{~S} \mathrm{Ct} 1419$ (1998) (Batson and Powers apply to grand juror selection). Thus since the McCleskey era, the Court appears to have moved toward an individualized understanding of the equal protection right, which in turn would suggest that only rational basis scrutiny would apply to a defendant's equal-protection challenge to victim-based discrimination in capital sentencing, unless the defendant were granted third-party standing to raise the rights of black victims. Note also that a defendant might be able to raise a due process challenge to victim-based racial discrimination in capital sentencing. See Peters $v$ Kiff, 407 US 493 (1972); Campbell, $118 \mathrm{~S} \mathrm{Ct}$ at $1424-25$.

${ }^{98}$ See, e.g., United States v Hays, 515 US 737, 745 (1995). 
constitutional, and the burden falls on the government to establish an extremely persuasive justification for use of that classification (a burden which is essentially never met). When a classification is subject only to rational basis review, however, the presumption is in favor of constitutionality, and the claimant has the burden of excluding all possible, legitimate justifications for the classification. Notice the consequence of this: if, as the above discussion suggests, the Court will sometimes subject an official racial classification to only rational basis scrutiny, then the use of race is not always, or even presumptively, unconstitutional. ${ }^{99}$ Therefore, in rational basis cases, simply proving that a racial classification was employed-in this context, that race was a cause of the decision to seek the death penalty - is insufficient to make out a valid claim. ${ }^{100}$ Something more is needed, and the Court's opinion in McCleskey might fairly be read to require that when a classification is subject only to rational basis review, a claimant may be required to introduce particularized evidence of "animus" on the part of the decision maker, because such a showing would tend to exclude the possibility of other legitimate justifications for the use of race. ${ }^{101}$ Under this view, the statistical evidence presented in the Baldus study, while perhaps sufficient to make out a prima facie case for unconstitutionality under the strict scrutiny standard, is almost surely insufficient under the rational basis standard because one can easily envision rational reasons why a prosecutor may take into account the race of a victim in determining whether to seek a death sentence, other than simple animus toward blacks. These might include concerns about the prosecutor's ability to prevail before a jury, combined with problems of limited resources. As noted above, such justifications caunot, under the Court's jurisprudence, survive strict scrutiny; but the same might not be true about rational basis review, with its strong presumption of constitutionality.

\footnotetext{
${ }^{99}$ Oddly, whether or not the classification is presumptively invalid will depend not on the nature of the classification, but on the identity of the plaintiff, since it is in cases where the classification turns on the race of a third party, rather than the plaintiff, that rational basis review is applied. If the third party challenged the classification, strict scrutiny would apply.

${ }^{100}$ Tbis is the strong implication of Justice O'Connor's opinion in Miller, which as explained above is consistent with the general tenor of the Court's current jurisprudence.

${ }^{101}$ Further support for this position can be found in the Court's recent decision in Romer $v$ Evans, $116 \mathrm{~S}$ Ct 1620 (1996), where a provision was struck down because it was found to be motivated by animus toward homosexuals. See generally Ashutosh Bhagwat, Purpose Scrutiny in Constitutional Analysis, 85 Cal L Rev 297, 327, 330 (1997).
} 
B. OVERVALUATION OF WHITE LIVES-BLACK VICTIM'S FAMILY SEEKS REMEDY

In Cell 2, the family of a black victim seeks the death penalty on the ground that there exists a difference in the treatment between killers of whites and blacks attributable to the overvaluation of white lives. ${ }^{102}$

Standing is an issue. What injury has the family suffered? The inclination would be to say they have suffered insufficient punishment of their relative's killer. But the overvaluation scenario posits that the killers of blacks receive an appropriate level of punishment. It is the killers of whites who are punished too severely.

The family might claim, however, that they have been stigmatized by the difference in treatment between killers of whites and the killer of their relative. ${ }^{103}$ Such a claim would raise an intriguing standing problem. In Allen $v$ Wright, ${ }^{104}$ the Court rejected the plaintiffs' claim of stigmatic injury resulting from race discrimina-

${ }^{102}$ One potential doctrinal barrier to judicial relief for black victims or their families can be quickly dismissed. Recent case law interprets the Due Process Clause of the Fourteenth Amendment as not requiring states to take positive action to protect their citizens. But these cases are not inconsistent with the view that the Equal Protection Clause sometimes might impose just such an obligation. In the leading case, DeShaney v Winnebago County Department of Social Services, 489 US 189 (1989), the Court held that "nothing in the Due Process Clause itself requires the State to protect the life, liberty, and property of its citizens against invasion by private actors. The clause is phrased as a limitation on the State's power to act, not as a guarantee of certain mimimum levels of safety and security." Id at 195. The Court also noted in its opinion, however, that its holding was limited to the question of whether the Due Process Clause imposed a general obligation to protect citizens; and, in particular, that the decision did not preclude an equal protection challenge to a state's failure to act, since " $[t]$ he State may not, of course, selectively deny its protective services to certain disfavored minorities without violating the Equal Protection Clause." Id at I973. Moreover, in Briscoe v LaHue, 460 US 325, 338 and $n 19$ (1983), the Court has specifically pointed to the historical context of the Equal Protection Clause, recognizing that a state's failure to equally protect citizens and punish those who commit violence against them violates the Fourteenth Amendment.

${ }^{103}$ Characterizing the injury as stigma eludes any problem that might otherwise be posed by Linda R.S. $v$ Richard D., 410 US 614 (I973). There, a woman sued for an injunction that would have required prosecutors to enforce the criminal child support law against the father of her illegitimate child. The Supreme Court held that she lacked standing. The Court ruled that nonenforcement of criminal laws does not constitute cognizable injuryin-fact. Id at 6I9. The plaintiff did suffer a different sort of injury-failure to receive support payments. However, it was not clear that the failure to enforce the child support law caused the husband to withhold support payments. Nor was it clear that enforcement of the law would actually produce such payments. Once the injury is recast as stigma, however, these problems disappear. Stigma from race discrimination is judicially cognizable. It is clearly caused by prosecutors' race-based actions, and it clearly would be redressed by an injunction against future race-based actions.

104468 US 747 (1984). 
tion on the ground that the stigma was too abstract. Parents of black public schoolchildren sued the Internal Revenue Service, alleging that it had failed to crack down on tax-exempt private schools that discriminated against blacks. The Court held that this claim of stigma failed to satisfy the "injury-in-fact" requirement:

[Plaintiffs do not] have standing to litigate their claims based on the stigmatizing injury often caused by racial discrimination. There can be no doubt that this sort of noneconomic injury is one of the most serious consequences of discriminatory government action and is sufficient in some circumstances to support standing. See Heckler $v$ Mathews, 465 U.S. 728, 739-740 (1984). Our cases make clear, however, that such injury accords a basis for standing only to "those persons who are personally denied equal treatment" by the challenged discriminatory conduct, ibid.

The consequences of recognizing respondents' standing on the basis of their first claim of injury illustrate why our cases plainly hold that such injury is not judicially cognizable. If the abstract stigmatic injury were cognizable, standing would extend nationwide to all members of the particular racial groups against which the Govenrment was alleged to be discriminating by its grant of a tax exemption to a racially discriminatory school, regardless of the location of the school. . . . A black person in Hawaii could challenge the grant of a tax exemption to a racially discriminatory school in Maine. Recogmition of standing in such circumstances would transform the federal courts into "no more than a vehicle for the vindication of the value interests of concerned bystanders." 105

In this passage, the Court says two things. First, it confirms that stigma from race discrimination constitutes injury-in-fact. Second, it states that the stigma must be peculiar to the claimants. In Cell 2 , the stigma meets this requirement. The claimants are the immediate relatives, and the stigma therefore affects them in a way that it does not affect anyone else. Even if the family's stigma is too attenuated, it can sue on behalf of the victim, who was "personally denied equal treatment." Thus, the stigma from differential prosecutorial treatment constitutes particularized injury-in-fact.

The next question is whether there exists a sufficient causal relationship between the stigma and the challenged conduct. One

${ }^{105}$ Id at 755-56 (citation omitted). 
might argue that there is no causal relationship because in Cell 2 -where we assume overvaluation of white lives-the harm is caused by the improper decisions to pursue the death penalty against killers of white victims in other cases, not by the decision to forgo the death penalty in the case at bar. But such an analysis is flawed. There is no reason to characterize the "challenged conduct" as the decision to forgo the death penalty in the present case rather than as the improper decisions to seek the death penalty in other cases. The fact that the plaintiff seeks to have the former decision reversed is irrelevant to causation. The issue of relief is not relevant in a standing analysis until the third stage-redressability. The challenged conduct in this case consists of the improper decisions to seek the death penalty in other cases, and those decisions clearly "cause" the plaintiffs' stigmatic injury.

The redressability inquiry asks whether the relief sought will redress the plaintiff's injury-in-fact. In Cell 2, the plaintiffs seek to have the prosecutor pursue the death penalty against the killer of their relative. Presumably, this would eliminate (or at least ameliorate) the stigma caused by differential prosecutorial treatment based on race.

Standing, then, is not a problem where the black victim's family seeks the death penalty. There is, however, a substantive barrier to the family's claim, tied to the remedy that they seek. Where the violation consists of the overvaluation of other lives, the Equal Protection Clause does not authorize an order requiring the prosecutor to seek the death penalty. Rather, the only proper remedy is to commute the death sentences of killers whose victims' lives were overvalued. It is true that either remedy would achieve equality. But where overvaluation of victims' lives is the problem, the Equal Protection Clause authorizes only a "leveling down"-here, commutation of death sentences. By the same token, when undervaluation is the problem, the clause authorizes only "leveling up"-imposition of the death penalty or damages.

This requires explanation. In every equal protection case where a governmental benefit has been denied a disfavored class, the court faces the choice in designing a remedy of extending the benefit to that class, or denying the benefit to all. ${ }^{106}$ It is sometimes

\footnotetext{
${ }^{106}$ See Welsh v United States, 398 US 333, 361 (1970) (Harlan, J, concurring in result).
} 
said that courts finding equal protection violations have discretion to choose their preferred remedy, and that the presumptive remedy is to extend the benefit to all. ${ }^{107}$ The Supreme Court's decisions clearly indicate, however, that this is incorrect. Instead, the proper remedy is determined by the ex ante intent of the legislature, or other government actor, that established or dispensed the benefit in the first place. The court is required to ascertain whether the governmental actor, blinded to the impermissible consideration, would have treated everybody at the favored group's level or the disfavored group's level. If the actor would have treated everybody at the favored group's level, then the disfavored group must be brought up to that level. If the actor would have treated everyone at the disfavored group's level, then the favored group must be brought down. ${ }^{108}$ Furthermore, this intent must be determined at the time the benefit was dispensed or the program established, not after litigation. ${ }^{109}$ This limitation is especially important when the relevant government actor is an individual rather than a legislature, because while a legislature may of course eliminate a benefits program at any time, even after litigation, and so ultimately impose a "leveling down" solution on all, ${ }^{110}$ permitting individuals to "choose a remedy" after litigation would in effect permit defendants to nullify constitutional rights based on nothing more than a promise to cease discriminating in the future.

In the context of discrimination in capital sentencing, the gov-

${ }^{107}$ The source of this confusion might he, at least in part, some language in the Supreme Court's opinion in Califano $v$ Westcott, 443 US 76, 89-90 (1979), indicating that ordinarily courts have treated the extension of henefits as the proper remedy.

${ }^{108}$ See Heckler $v$ Mathews, 465 US 728, 738-39 and n 5 (1984); Califano, 443 US at 90; id at 94 (Powell, J, concurring in part and dissenting in part); Miller $v$ Albright, $118 \mathrm{~S} \mathrm{Ct}$ $1428,1448-49$ (1998) (Scalia, J, concurring in the judgment); Note, Evan Caminker, $A$ Norm-Based Remedial Model for Underinclusive Statutes, 95 Yale L J 1185, 1187-88 (1986) (" $t$ ] he current remedial model requires courts to defer to the legislative branch and choose the option that they believe the enacting legislature would have preferred had it known that its intended discrimination was unlawful"). For example, if the legislature gave each white person $\$ 100$ and each non-white person nothing, tbe grant would violate equal protection. The relevant remedial question is how much the legislature-blinded to racewould have given each citizen. The answer may be $\$ 100$, nothing, or something in between. If the answer is $\$ 100$, then the court must award all non-white persons $\$ 100$. If the answer is nothing, then the court must prohibit the grant to white persons. If the answer is $\$ 50$, then the court must prohibit the state from giving white persons anything more than $\$ 50$, and it must award all non-white persons $\$ 50$.

${ }^{109} \mathrm{Id}$ at $1188 \mathrm{n} 9$.

${ }^{110}$ Compare Palmer v Thompson, 403 US 217 (1971). 
ernmental actor is the prosecutor. If, blinded to the victim's race, he would not have sought the death penalty against a particular defendant, then the proper remedy is to "level down"-that is, commute the defendant's sentence to life. If, blinded to the victim's race, he would have sought the death penalty against a defendant, then the proper remedy is to "level up." Ideally, this would consist of requiring the prosecutor to seek the death penalty, but because of practical problems, it may only consist of damages to the victim's family. ${ }^{111}$

In Cell 2, the violation is one of overvaluing white victims' lives. By definition, the prosecutors in those cases would not have sought the death penalty if they had ignored race. The correct remedy would be to commute any death sentences that were imposed in those cases. Thus the families in Cell 2 are not entitled to the remedy they seek, which is for the prosecutor to seek the death penalty against the killer of their loved one. This raises an interesting further question: Would an altruistic black family have standing to seek the commutation of the death sentences of killers whose white victims' lives were overvalued? The answer is no. There is nothing to differentiate one black victim's family from any other. In each of their cases, the prosecutor properly decided not to seek the death penalty. Their identical stigmatic injuries are caused by prosecutors elsewhere improperly deciding to seek the death penalty where the victims are white. The claim presents a "generalized grievance" falling outside the scope of Article III. Here, Allen $v$ Wright is directly on point. ${ }^{12}$ Clearly, the proper persons to seek commutation are the condemned defendants.

\section{UNDERVALUATION OF THE LIVES OF BLACK VICTIMS- DEFENDANT SEEKS COMMUTATION}

In Cell 3, the killer of a white person seeks to have his death sentence commuted on the ground that similarly situated killers of blacks receive life sentences. Cell 3 assumes that the life of the white victim has been properly valued, whereas the lives of similarly situated black victims have been undervalued.

We conclude that a defendant lacks standing to pursue such a

${ }^{111}$ See Part IV.D.

${ }^{112}$ See notes $104-05$ and accompanying text. 
claim because of the second element of the standing inquiry-causation. The defendant's injury is the death sentence, yet it was not caused by the undervaluation of the lives of black victims. Therefore, the defendant has no standing to seek commutation on the basis of the undervaluation of black lives. The defendant might portray his injury differently in an effort to create standing, but changing the injury also changes the remedy. The defendant might claim that his injury is not the death sentence itself, but rather being sentenced to death under a system that employs an arbitrary classification-race. Assuming that the courts would recognize such an injury, ${ }^{113}$ he would now have standing. However, he would not have standing to seek commutation. He would have standing only to seek resentencing under a nonarbitrary process. The proper remedy in this scenario is for him to be resentenced to death as part of a process that sentences all similarly situated killers of black victims to death. In theory, at least, this would be a hollow victory. ${ }^{114}$

Finally, even if the killer of a white did have standing to seek commutation of his death sentence based on the undervaluation of black victims' lives, he would run into the same remedial difficulties discussed in Cell 2. ${ }^{115}$ Since the constitutional violation identified by the defendant is undervaluation, the proper remedy is "leveling up," which is to say, sentencing killers of blacks to death, because by definition that is what prosecutors would have done if blinded to race. However, this remedy is not what the defendant is seeking, and helps him not at all.

\section{UNDERVALUATION OF BLACK VICTIMS' LIVES- POSSIBLE REMEDIES FOR FAM1LY}

In Cell 4 , the prosecutor undervalues the life of a black victim, and the victim's family seeks redress. Standing is not a barrier, for

${ }^{113}$ The extremely brief discussion of standing in McCleskey suggests that such an injury is cognizable, 481 US at 291-92 n 8, but serious questions might be raised about whether the current Court would consider such an injury sufficiently "concrete." See, e.g., Lujan $v$ Defenders of Wildlife, 504 US 555, 572-73 (1992).

${ }^{114}$ In practice, this remedy might be of some value to the defendant because of delays inherent in litigation.

${ }^{115}$ See Part IV.B. 
the reasons discussed in Cell 2. ${ }^{116}$ It is possible to imagine at least four different remedies in this situation, all problemmatic: an injunction to prevent future discrimination against black victims; allowing the victim's family to intervene in the penalty phase of the murder trial to seek the death penalty; damages against the prosecutor; and damages against the governmental unit employing the prosecutor.

1. Injunction. The victim's family could seek an injunction prohibiting discrimination against future black murder victims. The family could proceed individually or on behalf of the class of future black murder victims. Of course, any injunction would come too late to help the family's murdered relative. But, if the death penalty deters, it could help prevent future murders.

Such an attempt to secure injunctive relief would face daunting justiciability problems. The injunction would require prosecutors to pursue the death penalty in cases where they would otherwise be disinclined to seek it. Moreover, the lawsuit would be moot as to the victim. The "capable of repetition, yet evading review" doctrine would not apply because the same victim can never be murdered again. ${ }^{117}$ Although the family members are themselves potential murder victims, this is equally true of every black person in the jurisdiction. The family members can demonstrate no particularized injury in terms of future harm, and the Court has stated unequivocally that generalized grievances fall outside the scope of judicial power under Article III. ${ }^{118}$

\footnotetext{
${ }^{116}$ See Part IV.B. Remember that to state a cognizable claim, the family's alleged injury cannot be failure to punish its relative's killer, simipliciter, but rather it must be the stigma created by unequal treatment of their relative.

${ }^{117}$ See DeFunis v Odegaard, 416 US 312 (1974), in which a rejected law school applicant sued to gain admission on the ground that the school's affirmative action policy discriminated against him on the basis of race. The trial court ordered him admitted, and he matriculated during appeals. During oral argument to the Supreme Court, counsel for the school admitted that the plaintiff would receive his degree no matter how the Court ultimately ruled. The Court held that the case was moot and did not fall within the "capable of repetition, yet evading review" exception because the plaintiff himself "will never again be required to run the gantlet of the Law School's admission process, and so the question is certainly not 'capable of repetition' so far as he is concerned." Id at 319. The Court has since reaffirmed that the relevant question concerns the possibility of recurrence with respect to the complaining party, not others similarly situated. See Weinstein v Bradford, 423 US 147, 149 (1975); Murpby v Hunt, 455 US 478, 482 (1982).

${ }^{118}$ See Lajan $v$ Defenders of Wildlife, 504 US 555 (1992). The Court recently held that the prohibition against generalized grievances extends only to abstract injuries, not concrete ones. See Federal Election Comm'n v Akins, 118 S Ct 1777 (1998). It seems likely that the Court would find stigma more abstract than concrete.
} 
2. Intervention. Can the victim's family intervene in the penalty phase of the murder trial to compel the prosecution to seek the death penalty? We begin with a sketch of what such an intervention procedure might entail. The prosecutor would be required to announce a certain amount of time before trial whether he intends to seek the death penalty. The announcement of a decision not to seek the death penalty would trigger a brief period during which the black victim's next of kin would request a court order requiring the prosecutor to seek the death penalty. The trial court would then review the relevant statistical and other evidence to decide whether, if the victim had been white, the prosecutor would have sought the death penalty. If the court decides in the affirmative, then it would order the prosecutor to seek the death penalty.

The advantage of this procedure is obvious. The intervention is on behalf of a specific murder victim, not "all black victims," or "all potential black victims," and it cannot be denied that there exists a genuine, sharply defined "case or controversy" between the victim's family and the prosecutor. ${ }^{119}$ But intervention would cause intolerable delays. In order to decide whether the prosecutor had discriminated against the victim on the basis of race, the trial court would need to know the precise circumstances surrounding the killing. This would entail a mini-trial. Moreover, the court would have to consider the relevant statistical evidence and entertain argument regarding the charge of discrimination. Capital litigation is lengthy enough as it is. An intervention procedure is simply impracticable. ${ }^{120}$

3. Damages. Another possible remedy would be to allow the victim's family or the victim's estate damages from the prosecutor.

119 The prosecutor's failure to seek the death penalty creates a race-based difference in treatment that directly stigmatizes the family as well as the victim. See Part IV.B.

${ }^{120}$ Intervention proceedings could also hamper the prosecution's ultimate effort to obtain a conviction. Presumably the victim's family would want to call the prosecutor as an adverse witness during the intervention proceedings, or at least to cross-examine the prosecutor on his or her assertions. Not only would this distract the prosecutor from his or her trial preparation, it might also provide ammunition for the murder defendant. If the prosecutor testifies, the victim's family would offer all available impeachment evidence. Some of this evidence might prove embarrassing or outright damaging in the murder trial, or in any penalty phase that might ensue. On the other hand, if the intervention statute prohibits the victim's family from calling the prosecutor as an adverse witness, or prohibits them from cross-examination, it unfairly hamstrings the intervention effort. Still another problem with intervention is psychological. Formal and protracted adversary proceedings pitting the victim's family against the prosecutor are bound to dampen the prosecutor's zeal in obtaining "justice" for the victim. 
But the Supreme Court has held that prosecutors acting in their official capacity are absolutely immune from damages actions under Section 1983, so this remedy is currently unavailable. ${ }^{121}$

Could the victim's family or the victim's estate seek damages from the governmental unit employing the prosecutor? In Monell $v$ Department of Social Services, ${ }^{122}$ the Court ruled that a municipality is liable for damages under Section 1983 if the plaintiff demonstrates that a municipal custom or policy caused the violation. The municipality may not be held liable under a respondeat superior theory. Would a prosecutor's decision not to seek the death penalty on the basis of the victim's race constitute a "custom or policy" within the meaning of Monell?

The leading case in favor of characterizing such a decision as a "custom or policy" is Pembaur $v$ City of Cincinnati. ${ }^{123}$ A county prosecutor had instructed police to make an unconstitutional entry into a physician's clinic. The physician sued for damages under Section 1983. The Court held that the single decision of the prosecutor-who had authority under state law to decide whether the officers should enter- "may fairly be said to represent official policy." ${ }^{24}$ By analogy, the family of a black murder victim would argue that the prosecutor, having authority to decide what criteria should be employed in deciding whether to seek the death penalty, makes discriminatory policy every time he elects not to seek the death penalty because of the victim's race.

Since Pembaur, however, the Court has cut back on the situations in which the action of a municipal employee constitutes "custom or policy." 125 As one commentator has noted, "In all of the decisions following Monell, the Justices seem to be trying to limit local government liability to those situations in which fault can be attributed not simply to an individual officer but to the governmental entity itself." ${ }^{126}$ In $B d$. of County Commissioners of Bryan

${ }^{121}$ Butz v Economou, 438 US 478 (1978). Congress could, of course, eliminate prosecutors' immunity from damages, but it seems unlikely to do so.

122436 US 658 (1978).

${ }^{123} 475$ US 469 (1986).

${ }^{124}$ Pembaur, 475 US at 480.

${ }^{125}$ See, e.g., City of St. Louis v Praprotnik, 485 US 112 (1988) (state law determines who is a policymaking official); City of Canton v Harris, 489 US 378 (1989) (municipal liability for "failure to train" only where officials harbored "deliberate indifference" to citizens).

${ }^{126}$ Richard H. Fallon et al, Hart and Wechsler's The Federal Courts and the Federal System 1131 (4th ed 1996). 
County $v$ Brown, ${ }^{127}$ for example, the plaintiff was a passenger in a car that had been chased by police. When a deputy sheriff ordered her out of the vehicle, she refused. He then pulled her out so violently that she suffered severe and permanent damage to both knees. She sued the county on the theory that the sheriff had failed adequately to review the deputy's background before hiring him. As it turned out, the deputy-who was the sheriff's nephew's son-had previously pleaded guilty to several offenses, including assault and battery, resisting arrest, and public drunkenness. The Court nonetheless rejected municipal liability. Specifically, a review of the deputy's criminal record would not have provided sufficient reason for the sheriff to conclude that the deputy's use of excessive force would be a "plainly obvious consequence of the hiring decision." ${ }^{128}$ More generally, the Court emphasized the need to find aggravated mental culpability before imposing municipal liability:

As our Section 1983 municipal liability jurisprudence illustrates . . . it is not enough for a Section 1983 plaintiff merely to identify conduct properly attributable to the municipality. The plaintiff must also demonstrate that, through its deliberate conduct, the municipality was the "moving force" behind the injury alleged. That is, a plaintiff must show that the municipal action was taken with the requisite degree of culpability and must demonstrate a direct causal link between the municipal action and the deprivation of federal rights. ${ }^{129}$

As we recognized in Monell and have repeatedly reaffirmed, Congress did not intend municipalities to be held liable unless deliberate action attributable to the municipality directly caused a deprivation of federal rights. ${ }^{130}$

Most prosecutorial discrimination against victims is probably unconscious. If Brown means that no municipal liability shall be imposed for anything less than "deliberate" or "intentional" wrongdoing, then municipal liability would ordinarily be unavailable to families of victims. Brown may not, however, stand for that

\footnotetext{
127117 S Cr 1382 (1997).

${ }^{128} \mathrm{Id}$ at 1392 (footnote omitted).

${ }^{129} \mathrm{Id}$ at 1388.

${ }^{130} \mathrm{Id}$ at 1394.
} 
proposition. In City of Canton $v$ Harris, ${ }^{131}$ the Court seemed to attribute great significance to the difference between active malfeasance and nonfeasance. The plaintiff in Harris had alleged that the city's failure to train its personnel properly caused her injury. The Court stated that a "failure to train" theory would withstand challenge only "where the failure ... amounts to deliberate indifference to the rights of persons with whom the police come into contact." ${ }^{132}$ Like Harris, Brown was a case of nonfeasance-failure to screen. ${ }^{133}$ It may be that culpability must rise to the level of "deliberate" or "intentional" only in these nonfeasance cases, and that the fault standard in cases of malfeasance is lower. ${ }^{134}$ Therefore, it is unclear under existing law whether a victim's family could obtain damages. For these reasons, it is our view that Congress should expressly amend Section 1983 to authorize such relief.

Where the governmental unit employing the prosecutor is a state rather than a municipality, there are additional procedural hurdles. The Court has held that states are not "persons" within the meaning of Section 1983 when being sued for retrospective relief such as damages. ${ }^{135}$ Moreover, the Eleventh Amendment generally bars federal courts from awarding damages against states in federal court. ${ }^{136}$ Congress should amend Section 1983 to make states "persons" for the limited purpose of damages in prosecutorial discrimination cases. It should also use its authority under Section 5 of the Fourteenth Amendment to abrogate states' Eleventh Amendment sovereign immunity in prosecutorial discrim-

131489 US 378 (1989).

${ }^{132}$ Id at 388 (emphasis added).

${ }^{133}$ For purposes of this article, we assume that it is both possible and sensible to distinguish between cases of malfeasance and cases of nonfeasance. This assumption may be improvident. Harris might well be characterized as a case of actively culpable administration, just as Brown could be viewed as a case of reckless hiring. Justice Frankfurter once admonished the Court for insisting upon "Year-Book distinctions between feasance and nonfeasance-a distinction that may have significance in the evolution of common-law notions of liability, but is inadmissible as a line between constitutionality and unconstitutionality." Lambert v California, 355 US 225, 231 (1957) (Frankfurter, J, dissenting). Discussion of this problem, however, would divert us from our more immediate objective of exploring possible remedies for prosecutorial discrimination against victims.

${ }^{134}$ Altbough the Court has squarely held that mere negligence does not rise to the level of a Due Process violation. See Daniels v Williams, 474 US 327 (1986); Davidson v Cannon, 474 US 344 (1986).

${ }^{135}$ See Will $v$ Michigan Dept of State Police, 491 US 58 (1989).

${ }^{136}$ See Edelman v fordan, 415 US 651 (1974). 
ination cases. ${ }^{137}$ Finally, Congress should waive federal sovereign immunity in cases alleging prosecutorial discrimination against victims on the basis of race in federal capital cases.

What are the final results of our matrix analysis? In Cell 1, we found that a defendant whose white victim's life was overvalued has both first- and (probably) third-party standing to seek commutation of his death sentence. He is better off asserting the equal protection rights of undervalued black murder victims because such a claim would trigger strict scrutiny; the claim based on his own equal protection rights would be reviewed for a rational basis only. In Cell 2, we found that the family of a black victim has standing to seek the death penalty based on the overvaluation of white lives, but that imposition of the death penalty is the wrong remedy. The proper remedy for overvaluation of white lives is to commute the death sentences of the murderers of white victimsa remedy that the family of a black victim has neither standing nor incentive to seek. In Cell 3, we found that the condemned murderer of a white person does not have standing to seek commutation of his death sentence based on the undervaluation of black lives in other cases, and in any event, commutation is not the proper remedy for such a violation. He may have standing to insist upon being resentenced to death by a process that sentences similarly situated killers of blacks to death, but such a remedy does him little good. In Cell 4, we concluded that the family of a black victim should be able to sue the relevant governmental unit for undervaluation of its relative's life. We argued that Congress should amend Section 1983 to allow damages against municipalities and states in cases of prosecutorial discrimination against victims, and that Congress should waive federal sovereign immunity in such cases.

\section{Conclusion}

Devising a remedial scheme for race-of-the-victim discrimination in capital sentencing is difficult, but not impossible. The

\footnotetext{
${ }^{137}$ See Fitzpatrick v Bitzer, 427 US 445 (1976) (Section 5 of Fourteenth Amendment authorized Congress to abrogate states' Eleventh Amendment sovereign immunity with respect to Title VII actions). Congress's abrogation powers pursuant to the Civil War amendments survived the decision holding that Congress has no authority to abrogate pursuant to Article I. See Seminole Tribe v Florida, 517 US 44 (1996).
} 
most promising solutions would be to allow defendants who murder whites to seek commutation of their sentences, and families of black victims to seek damages against the governmental units that employ prosecutors who discriminate. Each of these claimants could rely entirely on statistical evidence to make out a prima facie case of discrimination. Once the claimant has carried this burden, the burden should shift to the prosecutor to articulate a legitimate, nonracial rationale for seeking the death penalty in that particular case. If the prosecutor offers such a reason, the claimant should bear the ultimate burden of persuasion. To make these solutions work, several reforms are required. The Supreme Court should reinterpret the "intent" requirement of Washington $v$ Davis and Arlington Heights to mean that the result would have been different if the race of the affected party had been different, and should permit the use of statistical evidence to establish this "causation" requirement. Moreover, Congress should amend Section 1983 to permit damages actions against governmental entities whose prosecutors discriminate on the basis of the victim's race.

This proposal would improve the law. The Baldus and similar studies prove that prosecutors discriminate based on the race of murder victims. For courts and legislatures simply to shrug their shoulders and say nothing can be done fosters cynicism and disrespect for the criminal justice system. 